\title{
The freshwater snails (Gastropoda) of Iran, with descriptions of two new genera and eight new species
}

\author{
Peter Glöer ${ }^{1, \dagger}$, Vladimir Pešićc ${ }^{2, \ddagger}$ \\ I Biodiversity Research Laboratory, Schulstraße 3, D-25491 Hetlingen, Germany 2 Department of Biology, \\ Faculty of Sciences, University of Montenegro, Cetinjski put b.b., 81000 Podgorica, Montenegro \\ † urn:lsid:zoobank.org:author:8CB6BA7C-D04E-4586-BA1D-72FAFF54C4C9 \\ ¥ urn:lsid:zoobank.org:author:719843C2-B25C-4F8B-A063-946F53CB6327 \\ Corresponding author: Vladimir Pešić (vladopesic@gmail.com)
}

Academic editor: Eike Neubert | Received 18 May 2012 | Accepted 24 August 2012 | Published 4 September 2012

urn:lsid:zoobank.org:pub:35A0EBEF-8157-40B5-BE49-9DBD7B273918

Citation: Glöer P, Pešić V (2012) The freshwater snails (Gastropoda) of Iran, with descriptions of two new genera and eight new species. ZooKeys 219: 11-61. doi: 10.3897/zookeys.219.3406

\begin{abstract}
Using published records and original data from recent field work and revision of Iranian material of certain species deposited in the collections of the Natural History Museum Basel, the Zoological Museum Berlin, and Natural History Museum Vienna, a checklist of the freshwater gastropod fauna of Iran was compiled. This checklist contains 73 species from 34 genera and 14 families of freshwater snails; 27 of these species (37\%) are endemic to Iran. Two new genera, Kaskakia and Sarkhia, and eight species, i.e., Bithynia forcarti, B. starmuehlneri, B. mazandaranensis, Pseudamnicola georgievi, Kaskakia khorrasanensis, Sarkhia sarabensis, Valvata nowsharensis and Acroloxus pseudolacustris are described as new to science; Ecrobia grimmi (Clessin \& Dybowski, 1888), Heleobia dalmatica (Radoman, 1974) and Hippeutis complanatus (Linnaeus, 1758) are reported for the first time from Iran. Additional field work is highly desirable for a more appropriate evaluation of the extant freshwater snail biodiversity in Iran.
\end{abstract}

\section{Keywords}

Freshwater snails, checklist, new species, Iran

Copyright Peter Glöer,Vladimir Pešić. This is an open access article distributed under the terms of the Creative Commons Attribution License 3.0 (CC-BY), which permits unrestricted use, distribution, and reproduction in any medium, provided the original author and source are credited. 


\section{Introduction}

Considering the geographical position of Iran, a rich fauna of freshwater snails could be expected. A high level of endemism and a diverse mixture of Palaearctic and Paleotropical elements are characteristic of the Iranian freshwater fauna (Pešić and Saboori 2007).

Research of molluscs biodiversity in Iran has a relatively long tradition. In 1862, a group of Italian scientists undertook the first systematic expedition to Persia, which revealed a large number of molluscan samples. The results of this expedition have been published by Issel (1863). Two decades later, the mollusc fauna of the Caspian Sea was studied by Dybowski (1888). The first study on the molluscs diversity of inland water was done at the beginning of the $\mathrm{XX}^{\text {th }}$ Century by the Indian malacologists Annandale and his coauthors (Annandale and Prashad 1919, Annandale 1921, Annandale and Rao 1925) who studied the molluscan fauna of Seistan and Baluchistan Province. Biggs (1936, 1937, 1971) studied the malacofauna of the Central Plateau of Iran. In 1936 he noted: "Little has been written on the Mollusca of the Iranian Plateau. This was perhaps due to the inaccessibility of the interior in the past when the only method of travelling was by caravan". Forcart (1935) studied molluscs from the Mazandaran Province. Starmühlner and Edlauer (1957) published the results of the Austrian Iran expedition of 1949/50 and 1956. Later on, Starmühlner $(1961,1965)$ studied molluscs from Northern and Eastern Iran collected by the Austrian A. Ruttner. More recently, Mansoorian $(1986,1994,1998,2000)$ published on the molluscan fauna of Iran.

However, our knowledge of freshwater snails of Iran remains scanty. Despite a growing number of data over the last years, resulting from the expeditions of the junior author in 2005, 2007, and 2011, literature records of freshwater snails in Iran have remained scattered and unreviewed, hampering ecological and biogeographical analysis. To what extent is the area of Iran unique and important for freshwater snail biodiversity? This paper attempts to answer such questions by compiling data on water molluscs and their current geographic distribution in Iran.

\section{Material and methods}

The checklist of the freshwater snail fauna of Iran was compiled using published records and original data. The data from all publications were brought to the presently accepted state of taxonomy following Subba Rao (1989) (for Asian Fauna), Brown (1994) (for African Fauna) and Glöer (2002) (for the European Fauna), and papers published thereafter. Species referred to in postgraduate theses and scientific meetings are no formal publications and are consequently not considered herein.

During the field work, freshwater snails were collected by hand netting, sorted on the spot and preserved in $75 \%$ alcohol. The data and locations of the sampling sites, where the junior author collected in 2005, 2007 and 2011 are listed in Appendix 1. In the section 'New records' collecting site abbreviations derive from the geographical database Pešić. The type material will be deposited in the Zoological Museum Ham- 
burg (ZMH), Germany. Further, we had the opportunity to revise material of some Iranian freshwater snails deposited in the collections of the Natural History Museum Basel (NMB - Forcart's collection), Zoological Museum Berlin (ZMB) and Natural History Museum Vienna (NHMW - Edlauer's collection).

Not all species could be identified due to the sparsity of specimens and the noncharacteristic shells, especially of small hydrobioid snails. Furthermore, the Caspian Sea fauna is not considered in the present paper. The order of families follows Bouchet and Rocroi (2005).

\section{Results}

\section{Systematics}

\section{Family Neritidae Rafinesque, 1815 \\ http://species-id.net/wiki/Neritidae}

Remarks. Theodoxus and Neritina are distinguished from each other by their ontogeny (Bandel 2001). While the Theodoxus species hatch from the spawn as miniature adult, Nertina species leave their spawn as planktotrophic larva that will float in the sea for a more or less extended period before its metamorphosis to a crawling young. However, at the adult stage the taxonomic separation of species of the genera Theodoxus and Neritina is not always easy. As most of the Neritina spp. are marine species and usually have a denticulate border of the columella and two apophysis of the operculum, most species of the genus Theodoxus are limnic and have a smooth border of the columella and one apophysis (the "rib"); some also have a small apophysis, the peg, on the operculum (Glöer 2002). Further, in Neritina the peg is thick and strong, while in Theodoxus it is, if exists at all, small and weak. A revision of this family, particularly its subdivion in clearly defined genera is needed.

\section{Genus Neritina Rafinesque, 1815}

Type species. Nerita pulligera Linnaeus, 1758

\section{Neritina mesopotamica Martens, 1874}

http://species-id.net/wiki/Neritina_mesopotamica

Figs $2 \mathrm{a}-\mathrm{c}$

Records from Iran. Khuzestan Province (Mansoorian 2001).

Material examined. Zoological Museum Berlin (ZMB), "Neritina (Neritaea) anatolica var. mesopotamica, Ras el Ain, Mesopot. Hausknecht”.

Remarks. The height of the largest shell of the examined syntypes from Zoological Museum Berlin was $7 \mathrm{~mm}$. Mansoorian (1994) in his identification key described shell 


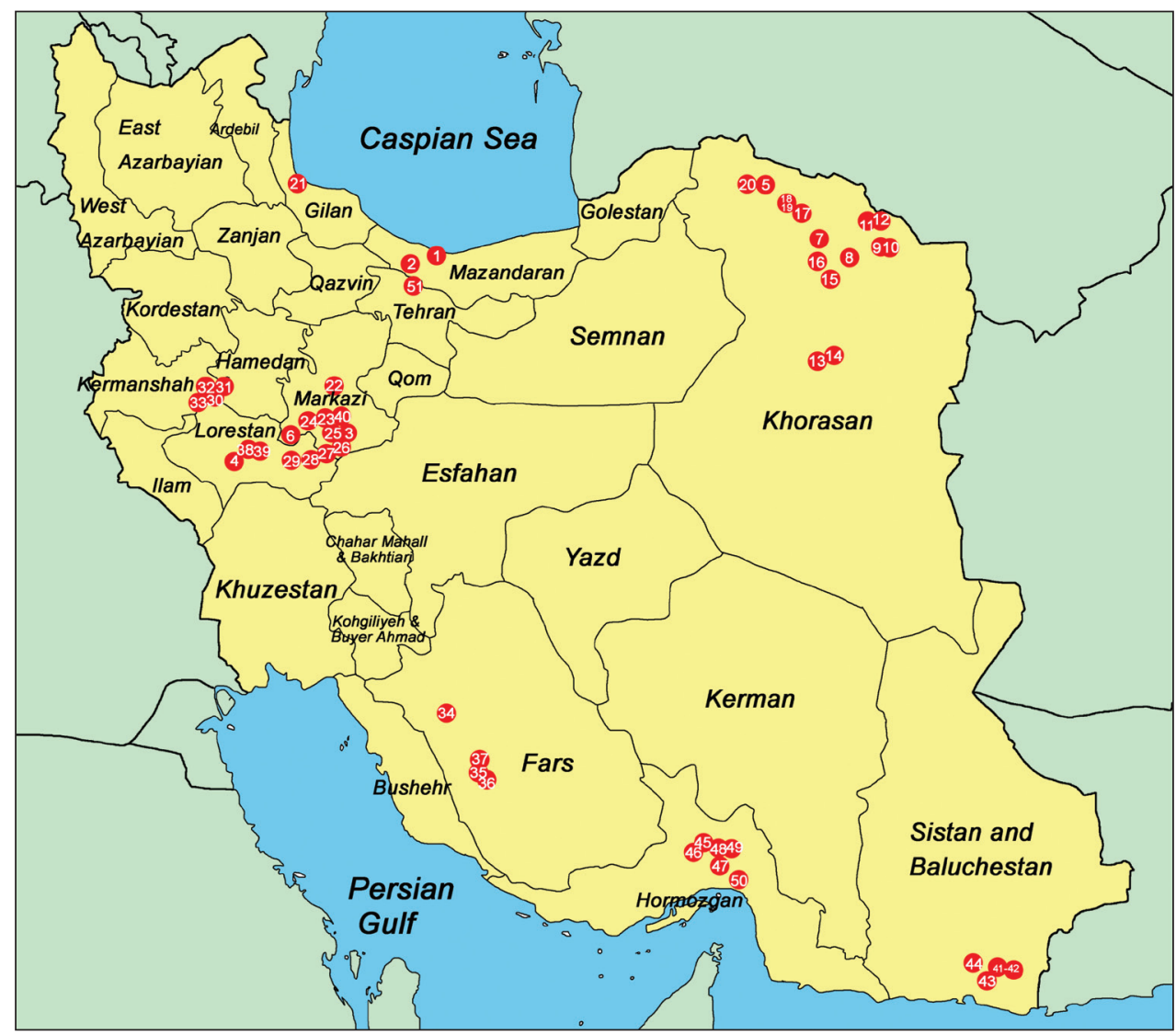

Figure I. Map of Iran with dots showing the collection localities (corresponding to the sampling site numbers in Appendix). The total number of freshwater mollusc species collected from each province are as follows (in parentheses): Bushehr (1), Fars (15), Gilan (12), Hormozgan (13), Isfahan (10), Kerman (15), Hermanshah (4), Khorasan (5), Khuzestan (14), Lorestan (6), Markazi (5), Mazandaran (21), Qom (1), Seistan and Baluchestan (16), Semnan (1), Teheran (5), West Azarbayjan (1), Yazd (6), Zanjan (1).

of this species as being $14 \mathrm{~mm}$ high. Considering his photos (Mansoorian 1994), he probably confused it with Neritina schlaeflii Mousson, 1874 (Figs 2f-g).

Distribution. Iraq, Iran (Khuzestan).

\section{Neritina cinctellus (Martens, 1874)}

http://species-id.net/wiki/Neritina_cinctellus

Syn.: Theodoxus cinctellus Martens, 1874

Records from Iran. Khuzestan Province (Chu et al. 1968, Massoud and HedayetiFar 1979). 


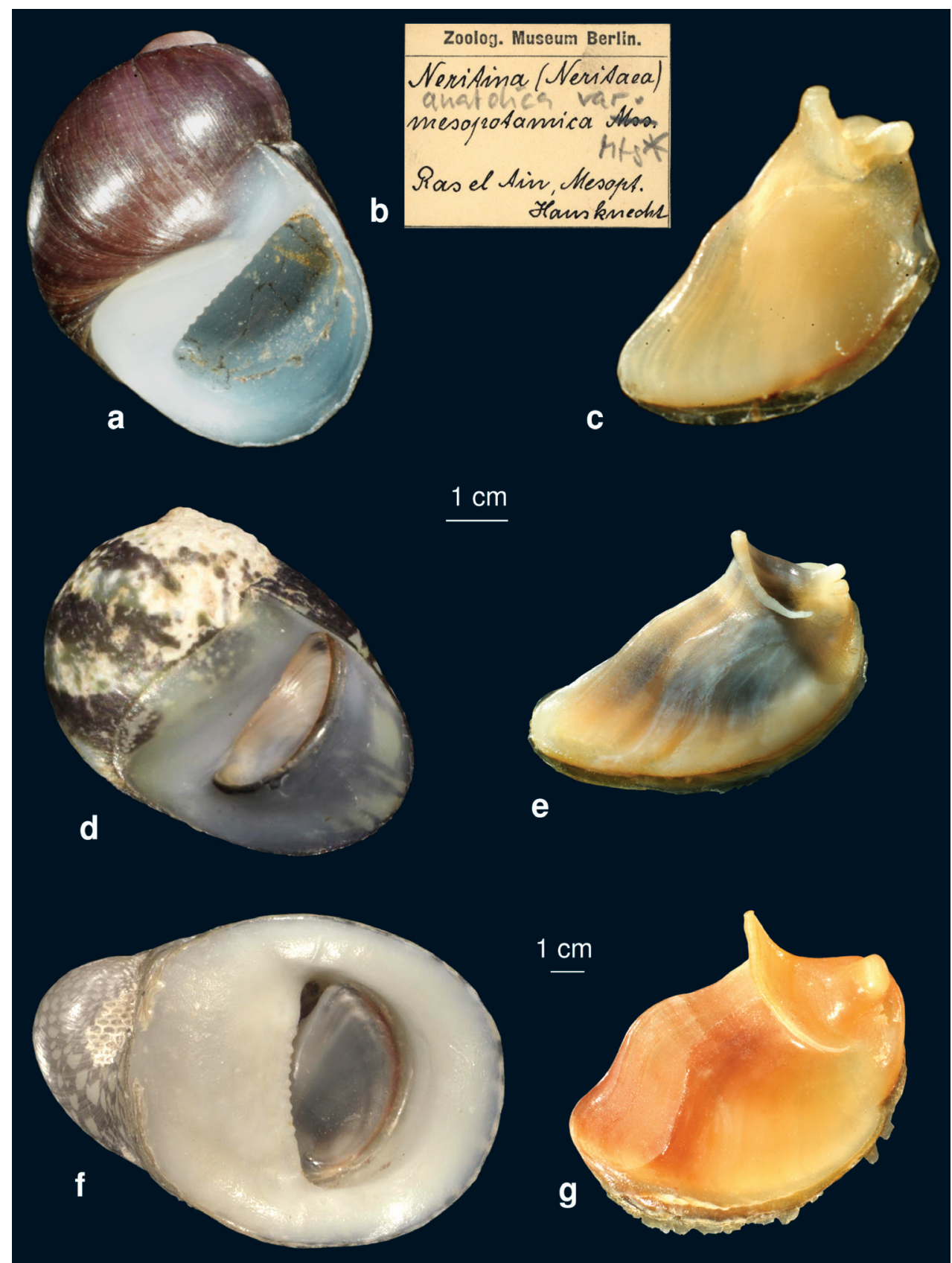

Figure 2. a-c Neritina mesopotamica d-e $N$. euphratica $\mathbf{f}-\mathbf{g} N$. schlaeflii a shell (syntype) b lable c operculum d shell (syntype, ZMZ 528916, Irak, Samava, photo: Eike Neubert) e operculum of $N$. euphratica from Euphrates f shell (syntype, ZMZ 529679, Persian Gulf, Island Ghaes, photo: Eike Neubert) $\mathbf{g}$ operculum of $N$. schlaeflii from Shatt Al-Arab-Fao region. 
Remark. According to the original description (Martens 1874) this species is characterized by the presence of denticulated border of the columella, and should be ascertained to the genus Neritina.

Distribution. Iraq, Iran.

\section{Neritina euphratica Mousson, 1874}

http://species-id.net/wiki/Neritina_euphratica

Figs $2 \mathrm{~d}-\mathrm{e}$

Records from Iran. Khuzestan Province (Massoud and Hedayeti-Far 1979, Mansoorian 2001).

Remark. This species is characterized by a small shell with $6 \mathrm{~mm}$ in height and a small spire. The boder of the columella is straight and not denticulated. The operculum has a rib which is attenuated at its basis, the peg is thick and strong and split in two parts (fig. 2e).

Distribution. Iraq, Iran.

\section{Genus Theodoxus Montfort, 1810}

Type species. Nerita fluviatilis Linnaeus, 1758

\section{Theodoxus fluviatilis (Linnaeus, 1758)}

http://species-id.net/wiki/Theodoxus_fluviatilis

Figs 3c, 11a

Theodoxus doriae Issel, 1865 (synonymy)

Records from Iran. (all mentioned as Th. doriae Issel): Kerman (Issel 1863, Martens 1874, Biggs 1937); Gilan, Mazandaran and Lorestan Province (Mansoorian 2000).

New records. Fars Province: IR13-07 [3 ex.]; IR14-07 [2 ex.]; Khorrasan Province: IR76-05 [1 ex]; IR 64-05 [1 ex.]; IR78a-05 [2 ex.]; IR79-05 [1 ex.]; Hormozgan Province: IR 17-11 [5 ex.]

Associated species. Melanopsis sp., Radix sp., Planorbis intermixtus, Farsithyra farsensis, Physella acuta.

Remarks. Martens (1879) synonymised Theodoxus doriae, the species reported by Issel (1863) from S Iran, with Th. fluviatilis. Later on, Mansoorian (2000) described the operculum of Th. doriae, which has only a rib, no peg. However, the shell illustrated by Mansoorian (1994) agrees well with Th. fluviatilis. Thus we follow Martens' (1879) synonymisation of Theodoxus doriae with Th. Aluviatilis. Our samples revealed only the presence of Th. fluviatilis. 


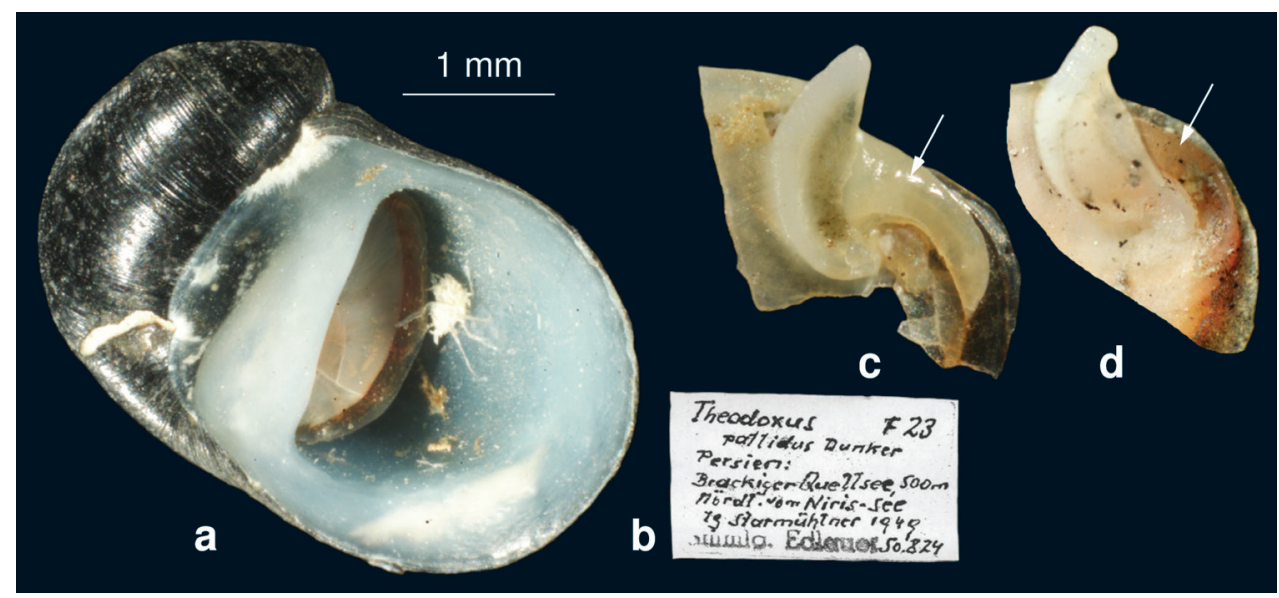

Figure 3. a-c Theodoxus pallida (from Edlauer's collection, NHMW 75000/E/50824) a Shell with corroded apex b label of Edlauer's collection c apophysis of Th. pallida $\mathbf{d}$ apophysis of Th. fuiviatilis (from IR79).

Distribution. W- to Central-Palaearctic. Theodoxus fluviatilis has been considered by many authors to be an exclusively European species (see e.g. Zhadin 1952, Glöer 2002). But Bourguignat (1864), Brown (1994) and van Damme (1984) mentioned it from NW Africa (Morocco, Algeria). Records of this species in Turkey (Yıldırım 1994), and in Iran, confirm its wide distribution. However, it does not occur in Siberia (Vinarski, pers. comm.).

\section{Theodoxus lituratus Eichwald, 1838}

http://species-id.net/wiki/Theodoxus_lituratus

Records from Iran. Kerman Province (Biggs 1971); Mazandaran Province (Eichwald 1838, Eliazian et al. 1979).

Remarks. This species has been described from the Caspian Sea. According to the original description (Eichwald 1838) this species is very distinct from the other Theodoxus spp. mentioned here.

Distribution. Iran.

\section{Theodoxus pallida Dunker, 1861}

http://species-id.net/wiki/Theodoxus_pallida

Figs $3 \mathrm{a}-\mathrm{b}$

Records from Iran. Isfahan and Fars Province (Starmühlner and Edlauer 1957).

Material examined. NHMW 75000/E/50824, “Theodoxus pallidus Dunker” Persien, Brackiger Quellsee, 500 m, nördl. vom Niris-see, leg. Starmühlner 1949. 
Remarks. Starmühlner and Edlauer (1957) provide a detailed description of the anatomy of this species but did not consider the operculum, the most important diagnostic feature. On the other hand, as figured in Starmühlner and Edlauer (1957), the receptaculum seminis and the bursa copulatrix differ in length (while being of equal length in Th. Aluviatilis).

The re-examination of the specimens of Theodoxus pallida (Dunker, 1862) from Edlauer's collection in NHMW clearly shows that this species is distinct from Theodoxus fluviatilis due to the shape of shell and the operculum (Fig. 3). As already mentioned by Dunker (1862) the spire in Th. pallida is higher than in Th. fluviatilis, and furthermore the apophysis of the operculum is broader and not attenuated at its basis (Fig. 3c). In addition the callus at border of the operculum in Th. pallida is much stronger (Fig. $3 \mathrm{c}$ arrow).

Distribution. Iran.

\section{Family Viviparidae J.E. Gray, 1847 \\ Genus Bellamya Jousseaume, 1886}

Type species. Paludina bellamya Jousseaume, 1886

Bellamya bengalensis (Lamarck, 1822)

http://species-id.net/wiki/Bellamya_bengalensis

Records from Iran. Khuzestan Province (Chu et al. 1968, Massoud and Hedayeti-Far 1979, Mansoorian 1994, 2001), Mazandaran Province (Mansoorian 2000).

Distribution. According to Ramakrishna and Dey (2007) this species is widely distributed on the Indian subcontinent.

\section{Bellamya hilmandensis (Kobelt, 1909)}

http://species-id.net/wiki/Bellamya_hilmandensis

Records from Iran. Seistan and Baluchestan Province (Annandale et al. 1919).

Distribution. Iran.

Family Melanopsidae H. \& A. Adams, 1854

Genus Melanopsis Férussac, 1807

http://species-id.net/wiki/Melanopsis

Type species. Buccinum praemorsum Linnaeus, 1758

Remark. Melanopsis praerosa L. is a misspelling of M. praemorsa $\mathrm{L}$. 


\section{Melanopsis costata (Olivier, 1804)}

http://species-id.net/wiki/Melanopsis_costata

Fig. 11e

Records from Iran. Kerman Province (Martens 1874); Khuzestan Province (Prashad 1921, Chu et al. 1968, as M. nodosa: Massoud and Hedayeti-Far 1979, Mansoorian 2001).

New records. Fars Province: IR13-07 [23 ad., 25 juv.].

Associated species. Farsithyra farsensis.

Distribution. Asia Minor, Syria, Palestine, Iraq, Iran.

\section{Melanopsis doriae Issel, 1865}

http://species-id.net/wiki/Melanopsis_doriae

Fig. 4

Records from Iran. Kerman Province (Issel 1863, Martens 1874, Biggs 1936, 1937, Starmühlner and Edlauer 1957, 1961, 1965); Fars Province (Starmühlner and Edlauer 1957); Yazd Province (Starmühlner and Edlauer 1957); Khuzestan Province (Mansoorian 1994, 2001); Mazandaran Province (Starmühlner and Edlauer 1957, Mansoorian 2000); Gilan Province (Starmühlner and Edlauer 1957); Bushehr Province (Starmühlner and Edlauer 1957).

New records. Hormozgan Province: IR17-11 [2 ex.]; IR19-11 [1 ex.].

Material examined. NHMW “Melanopsis doriae Issel” Persien, Kerman, aus teilweise eingestürztem Kanal, leg. Starmühlner 1949/50.

Associated species. Melanoides tuberculatus, Thiara scabra, Farsithyra farsensis.

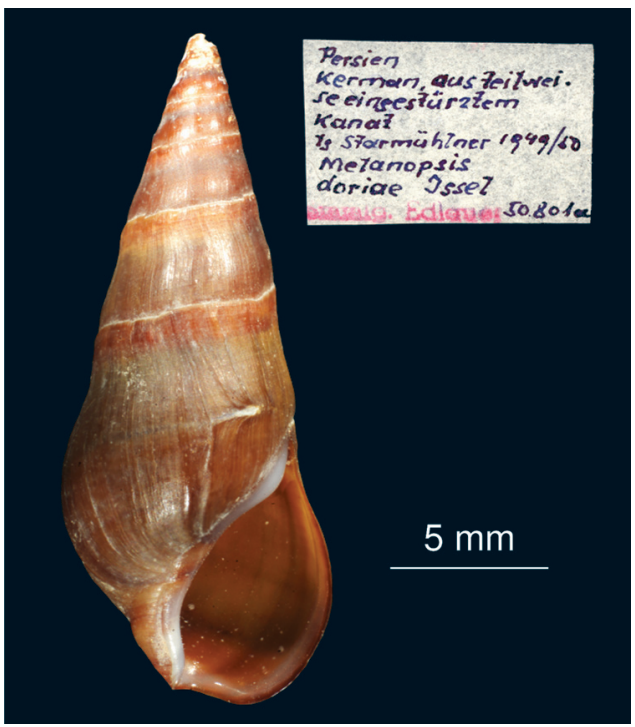

Figure 4. Melanopsis doriae (from Edlauer's collection, NHMW 750000/E/50801a): shell. 
Remarks. Starmühlner and Edlauer (1957) studied the anatomy of Melanopsis doriae and $M$. kotschyi showing differences in the nervous system. Furthermore they found differences in some features of the opercula between these species, and showed a strong morphological plasticity of the shells (see: Starmühlner and Edlauer 1957, plate 1: Figs g', g", g"' and h', h"). Re-examintion of Melanopsis doriae from Edlauer's collection in NHMW shows that the shell (Fig. 4) is slimmer than the shell of Melanopsis sp.

Distribution. Iran.

\section{Melanopsis kotschyi Philippi, 1847}

http://species-id.net/wiki/Melanopsis_kotschyi

Records from Iran. Fars Province (Starmühlner and Edlauer 1957).

Remarks. See remarks under previous species.

Distribution. Iran.

\section{Melanopsis sp.}

Fig. 11d

Records from Iran. Kerman Province (as Melanopsis variabilis: Martens 1874); Seistan and Baluchistan Province (as M. deserticola: Annandale and Prashad 1919); Isfahan and Yazd provinces (Biggs 1937); Fars province (as M. buccinoidea variabilis: Starmühlner and Edlauer 1957, as M. praerosa: Starmühlner 1961); Khuzestan Province (Chu et al. 1968, as M. praerosa: Massoud and Hedayeti-Far 1979, Manssorian 2001).

New records. Mazandaran Province: IR02-05 [11 ad., 48 juv.]; Khorrasan Province: IR64-05 [12 ad., 39 juv.]; IR79-05 [3 ad., 4 juv.]; IR78a-05 [8 ad., 15 juv.]; IR78c-05 [2 ex.]; Fars Province: IR17-07 [2 ex]; Hormozgan Province: IR19-11 [21 ex.].

Associated species. Galba truncatula, Theodoxus fuviatilis, Planorbis intermixtus, Grossuana sp., Farsithyra farsensis.

Remark. The species of this genus have a high morphological plasticity and many species have been described. Glaubrecht (1993) tried to solve the complicated taxonomy by proposing to consider all circum-Mediterranean Melanopsis spp. as being part of one 'superspecies', $M$. praemorsa. However, we follow Neubert (1998) who believes that this approach does not solve the problem. In recent literature the 'superspecies' notion tends to be abandoned and the former species names are being reinstituted (see: Heller et al. 2005; van Damme et al. 2010. This means that the smooth unsculptured species $M$. praemorsa sensu stricto (terra typica: Spain) is actually a western Mediterranean species and that unsculptured morphs from the Levant belong to other species, such as M. buccinoidea, ammonis, 
dircaena, khabourensis and meiostoma (Heller et al. 2005). Those from Mesopotamia have been described under M. variabilis, deserticola, buccinoidea and praemor$s a$. Further study is necessary to establish under which name or names the Iranian populations should be placed.

Family Potamididae H. \& A. Adams, 1854

Genus Cerithidea Swainson, 1840

Type species. Cerithium obtusum Lamarck, 1822

Cerithidea cingulata (Gmelin, 1790)

http://species-id.net/wiki/Cerithidea_cingulata

Fig. 8c

Records from Iran. Hormozgan Province (Ghasemi et al. 2011).

New records. Hormozgan Province: IR14-11 [21 ad., 6 juv.]; IR-20-11 [10 ex.].

Associated species. Ecrobia grimmi, Pseudamnicola sp.

Distribution. Indo-Pacific coast.

Family Thiaridae Gill, 1871

Genus Thiara Roeding, 1798

Type species. Helix amarula Linnaeus, 1758

Thiara scabra (O.F. Müller, 1774)

http://species-id.net/wiki/Thiara_scabra

Fig. 12c

Records from Iran. Seistan and Baluchestan Province (as Melanoides scabra var. elegans: Annandale and Prashad 1919); Isfahan Province (as M. scabra: Biggs (1937); Hormozgan Province (Starmühlner and Edlauer 1957).

New records. Hormozgan Province: IR08-11 [13 ex.]; IR17-11 [2 ex.].

Associated species. Farsithyra farsensis, Melanoides tuberculatus, Physella acuta, Melanopsis doriae.

Distribution. Indo-Pacific coasts. 


\section{Genus Melanoides Olivier, 1804}

Type species. Melanoides fasciolata Olivier, $1804=$ Nerita tuberculata O.F. Müller, 1774.

\section{Melanoides tuberculatus (O.F. Müller, 1774)}

http://species-id.net/wiki/Melanoides_tuberculatus

Fig. $12 b$

New records. Seistan and Baluchestan Province: IR8a-11 [5 juv.], IR8-11 [18 ex.]. Hormozgan Province: IR10-11 [3 ex.], IR17-11 [10 ad., 9 juv.], IR18-11 [1 ad., 8 juv.], IR19-11 [2 ex.].

Associated species. Melanopsis doriae, Thiara scabra, Farsithyra farsensis.

Records from Iran. Kerman Province (as Melania tuberculata: Issel 1863), Martens 1874, Biggs 1936, 1937, Starmühlner and Edlauer 1957); Seistan and Baluchestan Province (as M. pyramis, M. tigrina: Annandale and Prashad 1919, Biggs 1937); Hormozgan Province (Biggs 1937, Starmühlner and Edlauer 1957), (as Melania tuberculata: Starmühlner (1961); Isfahan Province (Biggs 1937); Yazd Province (Starmühlner and Edlauer 1957, as Melania tuberculata: Starmühlner 1965); Khuzestan Province (Chu et al. 1968, Mansoorian 2001); South Iran (Manssorian 1994); Fars Province (Starmühlner and Edlauer 1957): Mazandran Province (Starmühlner and Edlauer 1957, Mansoorian 2001).

Remarks. The species Melanoides pyramis and M. tigrina, which have been mentioned by Annandale and Prashad (1911) from Seistan and Baluchistan, have been listed by Westerlund (1886) as subspecies. However, due to the high morphological plasticity of $M$. tuberculatus and in absence of any geographical seperation of these taxa, we list all Melanoides taxa under $M$. tuberculatus.

Distribution. S Asia, Arabia, Near East, Africa.

\section{Family Bithyniidae J.E. Gray, 1847}

\section{Genus Bithynia Leach, 1818}

Type species. Helix tentaculata Linnaeus, 1758

Bithynia (Bithynia) tentaculata (Linnaeus, 1758)

http://species-id.net/wiki/Bithynia_tentaculata

Records from Iran. Mazandaran Province (Mansoorian 2000); Gilan and Lorestan Province (Mansoorian 2000).

Rejected records. Mazandaran Province (Forcart 1935). 
Remarks. The Euro-Siberian species Bithynia tentaculata (Linnaeus 1758) has often been mentioned from Iran, Turkey and Greece. However, this species could not be found in Greece (Glöer et al. 2010) and probably does not occur in Turkey. The southern distribution border of this species lies possibly in N Bulgaria (Georgiev pers. comm.). An analysis of the specimens from NMB published by Forcart (1935) as Bithynia tentaculata shows that these specimens represent $B$. forcarti sp. n. (see below). Thus, $B$. tentaculata most probably does not occur in Iran and has been confused with B. forcarti sp. n. or possibly with Bithynia mazandaranensis sp. n. (see below).

Distribution. Euro-Siberian.

\section{Bithynia (Bithynia) forcarti sp. n.}

urn:lsid:zoobank.org:act:8A83711B-797D-4D86-99D5-72F217B14A89

http://species-id.net/wiki/Bithynia_forcarti

Figs $5 \mathrm{a}-\mathrm{b}$

Type locality. Mazandaran Province, Tschalekuti.

Holotype (NMB 11517a): shell height $7.5 \mathrm{~mm}$, width $5.6 \mathrm{~mm}$.

Paratypes. Mazandaran Province, Tschalekuti (NMB 11517a, 26 ex.), Geniste d. Babul (NMB 11517b, 1 ex., NMB 11571c, 10 ex.)

Etymology. Named after Lothar Forcart in appreciation on his studies of Iranian freshwater snails.

Description. The whitish shell is conical with 5.5 whorls, which are convex with a deep suture and a small and acute apex. The convex whorls are flattened at the suture. The umbilicus is open. The aperture is ovate, angled at the top. The margin of the aperture is, from lateral view, slightly sinuated. The surface is smooth with fine growth lines. Shell height $5.5-7.5 \mathrm{~mm}$, width $5.0-5.6 \mathrm{~mm}$.

Differentiating features. Due to the shape of the aperture (angled at the top), Bithynia forcarti sp. n. resembles B. mazandaranensis sp. n. (see below). However, from the latter species it can be easily distinguished by the stepped whorls.

Remarks. Formerly (Forcart 1935) this species has been confused with B. tentaculata.

\section{Bithynia (Bithynia) starmuehlneri sp. $\mathrm{n}$.}

urn:lsid:zoobank.org:act:5A63D216-B630-4808-8B2D-0F77E3EAE287

http://species-id.net/wiki/Bithynia_starmuehlneri

Figs $6 \mathrm{a}-\mathrm{c}$

Bulimus (Bithynia) leachi troschelii: Starmühlner and Edlauer 1957, non troschelii Paasch, 1842 (synonymy)

Type locality. Border of Lake Urmia, W Azarbayian, 1949 leg. Starmühlner.

Holotype. NHMW (50940): shell height $10.3 \mathrm{~mm}$, width $5.6 \mathrm{~mm}$. 


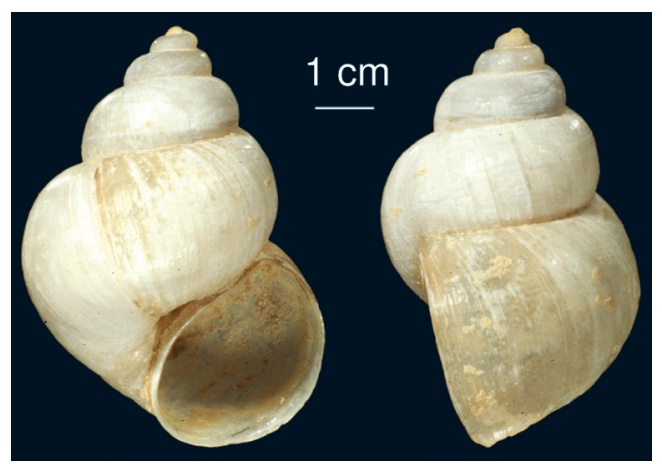

Figure 5. Bithynia forcarti sp. n. a shell, frontal view b shell, lateral view.

Paratypes. 9 ex. from the type locality.

Etymology. Named after Ferdinand Starmühlner, who collected this species in 1949.

Description. The whitish shell is elongated conical with 6.5 whorls, which are convex with a deep suture and a small and acute apex. The umbilicus is open. The aperture is ovate. The margin of the aperture is, from lateral view, straight. The surface is smooth with fine growth lines. Shell height $8.2-10.3 \mathrm{~mm}$, width $4.6-6.4 \mathrm{~mm}$.

Differentiating features. This slim species is the largest Bithynia sp. known in Iran. It can be easily distinguished from the other Bithynia spp. by the larger dimensions of elongated shell with the stepped whorls and the not angled aperture.

Remarks. This species has been misidentified by Starmühlner and Edlauer (1957) with $B$. troschelii.

\section{Bithynia (Bithynia) mazandaranensis sp. $\mathrm{n}$.}

urn:Isid:zoobank.org:act:22D0892E-8670-4131-9149-0F77C007BB94

http://species-id.net/wiki/Bithynia_mazandaranensis

Figs $7 \mathrm{a}-\mathrm{d}$

Type locality. Mazandaran Province, Nowshahr city, pond near Caspian Sea, 51⒊'E, $36^{\circ} 38^{\prime} \mathrm{N}, 18$ June 2005.

Holotype (ZMH 79369): Shell height $8.0 \mathrm{~mm}$, width $5.0 \mathrm{~mm}$.

Etymology. Named after the region where the species was collected.

Description. The horn-coloured shell is conical with 5.5 whorls, which are slightly convex with a clear suture and an acute apex. The umbilicus is closed. The aperture is ovate, angled at the top. The margin of the aperture is, from lateral view, sinuated. The surface bears a lattice structure. Shell height $8.0 \mathrm{~mm}$, width $5.0 \mathrm{~mm}$, aperture height $3.6 \mathrm{~mm}$. 


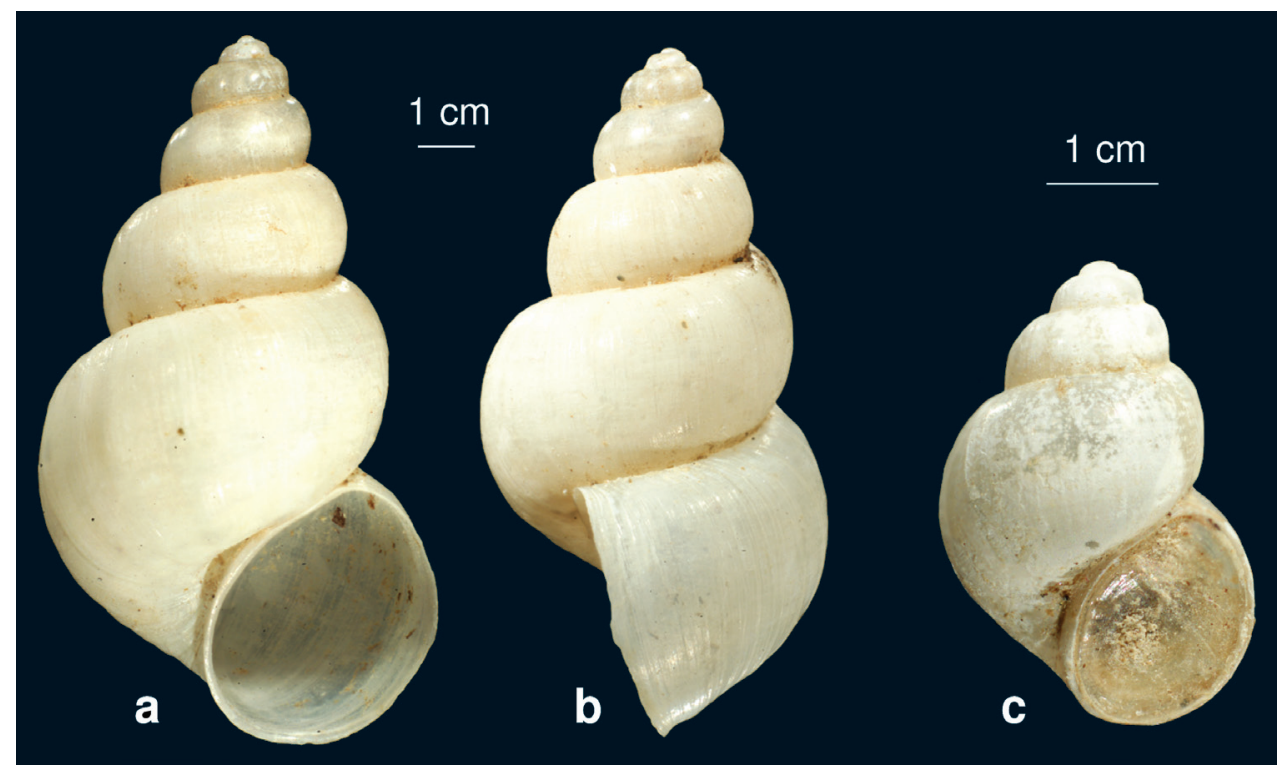

Figure 6. Shell of Bithynia starmuehlneri sp. n. a frontal view b lateral view $\mathbf{c}$ juvenile shell with operculum.

Differentiating features. The new species resembles $B$. tentaculata but differs from it by the following features: (i) the operculum is more angled (Fig. 7c), (ii) the whorls are more convex (Fig. 7a-b), and (iii) the surface has longitudinal and transverse striae (Fig. 7d).

Associated species. Planorbis carinatus, Anisus sp., Valvata cristata, Valvata nowshahrensis sp. n., Hippeutis complanatus.

Remarks. Probably this species formerly (e.g., Mansoorian 2000) was confused with $B$. tentaculata. Because we had only an empty shell of this species, we do not know if it belongs to the genus Bithynia or Pseudobithynia, so our generic assignment is tentative. To address this question, anatomical studies of more specimens are necessary.

\section{Bithynia (Bithynia) cf. ejecta Mousson, 1874}

Records from Iran. Isfahan Province - (as Amnicola ejecta: Biggs 1937).

Remarks. Probably due to the small size of this species, Biggs (1937) assigned this species belongs to the genus Amnicola, although Mousson (1874) described it as a Bythynia, and pointed out that the operculum is characteristic for Bythinia and different from Amnicola (syn. to Pseudamnicola). Furthermore, Biggs (1937) found his species in the mountains, while the original description of Bithynia ejecta comes from the lowland, indicating the Biggs's species is not conspecific with Bithynia ejecta and probably represents an undescribed species. 


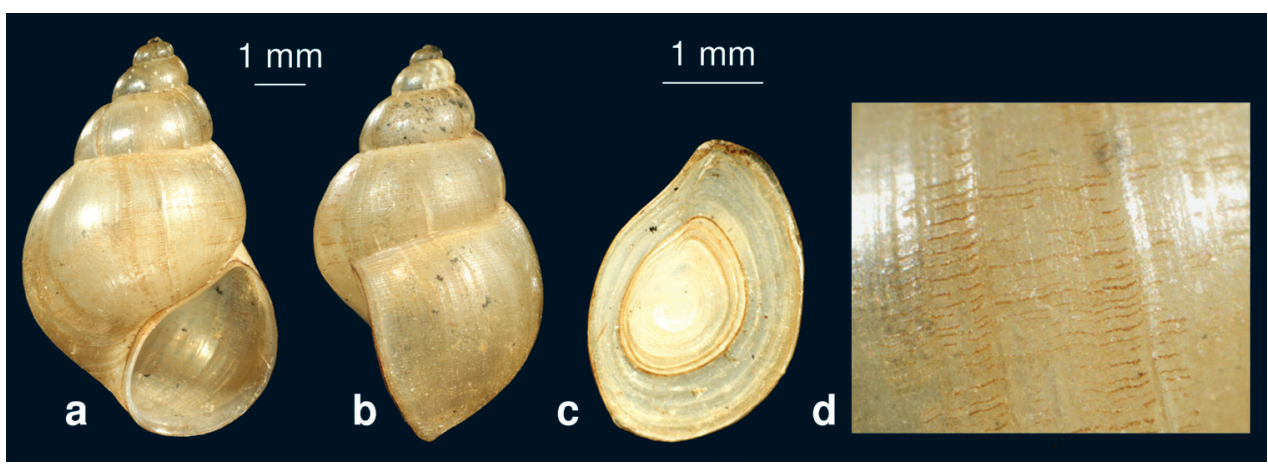

Figure 7. Bithynia mazandaranensis sp. n. a, b shell $\mathbf{c}$ operculum $\mathbf{d}$ detail of the shell surface.

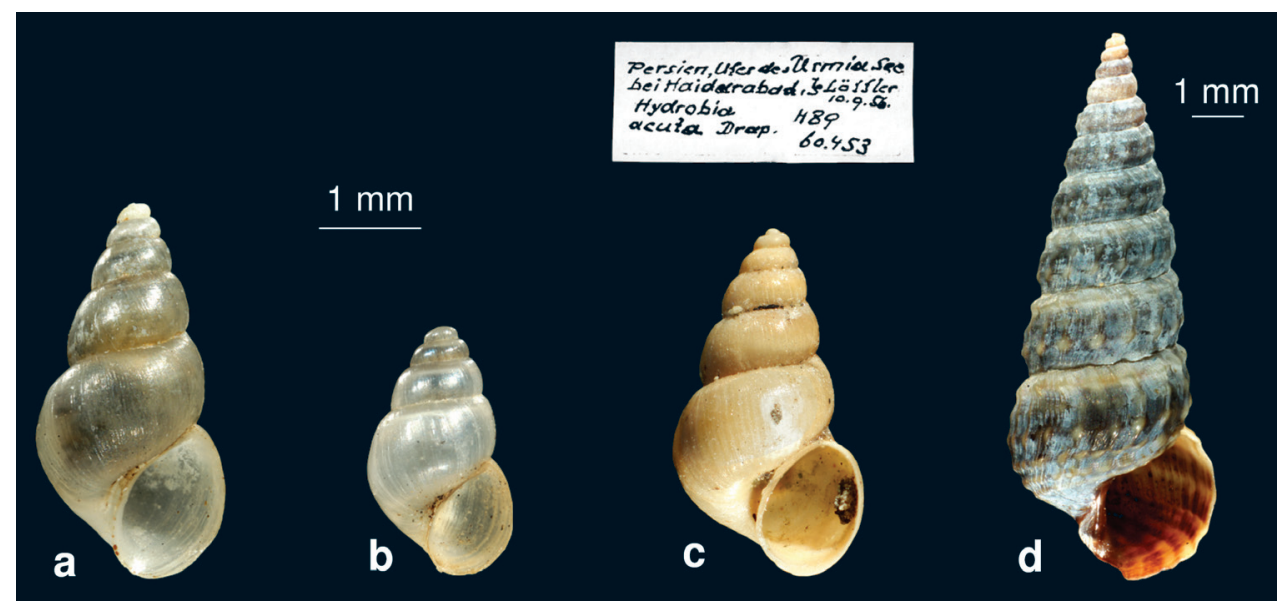

Figure 8. The molluscs of brackish waters. a Ecrobia grimmi $\mathbf{b}$ Heleobia dalmatica $\mathbf{c}$ Ecrobia grimmi from Edlauer's collection (NHMW, "Hydrobia acuta" 75000/E/60453) d Cerithidea cingulata.

Bithynia (Bithynia) rubens (Menke, 1830)

http://species-id.net/wiki/Bithynia_rubens

Records from Iran. North Iran (Caspian Sea) - Eliazian et al. (1979).

Remarks. This species could not be found in any of the neighbouring countries of Iran. Eliazian et al. (1979) don't mention the source that led to their identification. The record and taxonomic status of this species is questionable and needs new confirmation.

\section{Subgenus Gabbia Tryon, 1865}

Type species. Gabbia australis Tryon, 1865 
Remarks. Some authors (e.g Subba Rao 1989, Nesemann et al. 2007) mention Gabbia as a genus. However, it seems not possible to distinguish the genera of the Bithyniidae by the shape of opercula (Mandahl-Barth 1968) and/or by shell forms, because these characters are found to be variable. On the other hand, the examined material of the family of Bithyniidae can be easily separated by the characteristics of penis morphology (having a penial appendix: Bithynia Leach 1818; or lacking a penial appendix: Pseudobithynia Glöer \& Pešić 2006). In our study, we tentatively use the name Gabbia as a subgenus for small Bithynia species with a globular shell, originating from India.

Bithynia (Gabbia) sistanica (Annandale \& Prashad, 1919) http://species-id.net/wiki/Bithynia_sistanica

Records from Iran. Seistan and Baluchestan Province (as Amnicola sistanica: Annandale and Prashad 1919).

Remark. Annadale and Prashad (1919) described this species as Amnicola (Alocinma) sistanica and depicted the penis morphology. Due to the presence of a penial appendix this species is ascertained to the genus Bithynia. The members of the genus Pseudamnicola (formerly Amnicola) have no penial appendix.

Distribution. Iran; only known from N Seistan.

Genus Pseudobithynia Glöer \& Pešić, 2006

Type species. Pseudobithynia irana Glöer \& Pešić, 2006

Pseudobithynia irana Glöer \& Pešić, 2006

http://species-id.net/wiki/Pseudobithynia_irana

Fig. $12 \mathrm{k}$

Records from Iran. Markazi and Lorestan Provinces (Glöer and Pešić 2006).

New records. Lorestan Province: IR26-07 [10 ex.].

Associated species. Planorbis intermixtus, Radix sp.

Distribution. Iran; Markazi and Lorestan Provinces.

Pseudobithynia zagrosia Glöer \& Pešić, 2009

http://species-id.net/wiki/Pseudobithynia_zagrosia

Fig. 121

Records from Iran. Fars Province (Glöer and Pešić 2009). 
Distribution. Iran; known only from the locus typicus (Dasht Arzhan village, Shiraz to Kazerum road).

\section{Family Cochliopidae Tryon, 1866}

Genus Heleobia Stimpson, 1865

Type species. Heleobia stagnorum (Gmelin, 1791)

\section{Heleobia dalmatica (Radoman, 1974)}

http://species-id.net/wiki/Heleobia_dalmatica

Fig. $8 b$

New records. Hormozgan Province: IR14-11 [12 ad., 20 juv.].

Associated species. Cerithidea cingulata, Ecrobia grimmi, Pseudamnicola sp.

Remarks. New for Iran.

Distribution. Previously only known from the brackish part of rivers along the coast of Croatia (Radoman 1983).

\section{Family Hydrobiidae Stimpson, 1865}

Genus Hydrobia Hartmann, 1821

Type species. Cyclostoma acutum Draparnaud, 1805

Hydrobia acuta (Draparnaud, 1805)

http://species-id.net/wiki/Hydrobia_acuta

Records from Iran. Isfahan Province (Biggs 1971).

Rejected records. Fars Province (Starmühlner and Edlauer 1957).

Remark. Probably this species has been confused with one of the following species (Ecrobia grimmi, Heleobia dalmatica), so all former records of this species in Iran are questionable. The record for this species is kept until the original material of Biggs could be studied.

Genus Ecrobia Stimpson, 1865

Type species. Turbo ventrosus Montagu, 1803 
Ecrobia grimmi (Clessin \& Dybowski, 1888)

http://species-id.net/wiki/Ecrobia_grimmi

Figs $8 \mathrm{a}, \mathrm{c}$

New records. Hormozgan Province: IR14-11 [12 ad., 20 juv.].

Associated species. Cerithidea cingulata, Heleobia dalmatica, Pseudamnicola sp.

Remarks. On the base of molecular results, Haase et al. (2010) concluded that Ecrobia grimmi from the mixomesohaline Lake Sawa (Iraq) was possibly transported by migrating birds from the Caspian Sea. The identification of our material of Ecrobia grimmi as well of Heleobia dalmatica was confirmed by using molecular techniques (Martin Haase pers. communication). An analysis of the specimens from NHMW published by Starmühlner and Edlauer (1957) as Hydrobia acuta shows that these specimens probably belong to Ecrobia grimmi (see Fig. 8c).

Distribution. Caspian Sea; Iraq, Iran.

Genus Pseudamnicola Paulucci, 1878

Type species. Bithynia lucensis Issel, 1866

Pseudamnicola kotschyi v. Frauenfeld, 1863

http://species-id.net/wiki/Pseudamnicola_kotschyi

Records from Iran. Isfahan Province (Starmühlner 1961, 1965).

Distribution. Iran: Isfahan Province; endemic.

Pseudamnicola saboori Glöer \& Pešić, 2009

http://species-id.net/wiki/Pseudamnicola_saboori

Fig. $12 \mathrm{~h}$

Records from Iran. Khorasan and Markazi Provinces (Glöer and Pešić 2009).

Distribution. Iran: Khorasan and Markazi Provinces.

Pseudamnicola zagrosensis Glöer \& Pešić, 2009

http://species-id.net/wiki/Pseudamnicola_zagrosensis

Fig. $12 \mathrm{i}$ 
Records from Iran. Kermanshah Province - Glöer and Pešić (2009).

Distribution. Iran: Kermanshah Province.

\section{Pseudamnicola raddei Boettger, 1889}

http://species-id.net/wiki/Pseudamnicola_raddei

Records from Iran. Mazandaran Province - Forcart (1935).

Distribution. Transcaspian region (Zhadin 1952).

Remarks. In Russia it is listed as Turkmenamnicola raddei (Kantor et al. 2009).

\section{Pseudamnicola georgievi sp. $\mathbf{n}$.}

urn:Isid:zoobank.org:act:D2E680D0-AAC4-45DF-954A-28D553EC957F

http://species-id.net/wiki/Pseudamnicola_georgievi

Fig. 9

Type locality. Markazi Province, Ashtian to Arak road (ca. $5 \mathrm{~km}$ after Ashtian city, Ashtian county), 50 $01^{\prime} \mathrm{E}, 34^{\circ} 34^{\prime} \mathrm{N}$, ca. $1800 \mathrm{~m}$ asl., 21 June 2005.

Holotype (ZMH 79370): Shell height $2.6 \mathrm{~mm}$, width $1.9 \mathrm{~mm}$.

Paratypes (ZMH 79371): 6 ex. from type locality.

Etymology. Named after Dr. Dilian Georgiev in appreciation of his studies on Bulgarian hydrobiids.

Description. The whitish shell is conical with 4.5 whorls, which are separated by a clear suture. The surface is glossy and finely striated. The apex is blunt, the umbilicus is closed, the aperture is ovate and pointed at the top. Shell height 2.4-2.6 $\mathrm{mm}$, width $1.9 \mathrm{~mm}$.

Differentiating features. The conical shell with its pointed aperture (Fig. 9) clearly distinguished the new species from other Iranian members of the genus Pseudamnicola.

Remark. We had only shells with dried tissue at our disposal. Since the penis morphology could not be examined, the assignment to the genus Pseudamnicola is provisional.

Distribution. Iran; only known from the type locality.

\section{Genus Kaskakia gen. n.}

urn:Isid:zoobank.org:act:31BFCB62-BE86-43CE-A888-B0562CC2740E

http://species-id.net/wiki/Kaskakia

Diagnosis. Shell conical. Penis broad at the basis, distal part with a bulbous and acute penis tip.

Type species. Kaskakia khorrasanensis sp. n.

Etymology. Named after the region where the species was collected. 


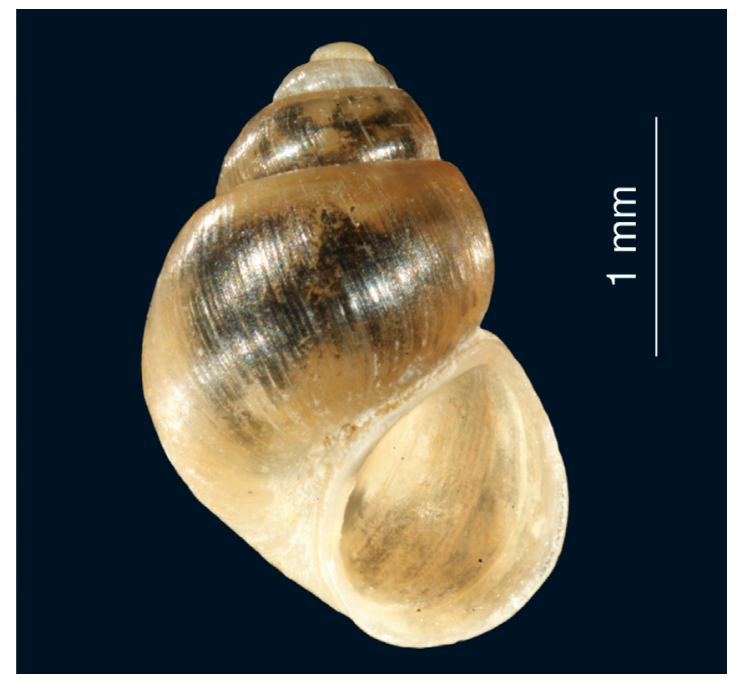

Figure 9. Pseudamnicola georgievi sp. n.: shell.

Differential diagnosis. The new genus appears to be close to Pseudamnicola, but can easily be distinguished by the unique morphology of the penis with bulbous and acute apex (vs. a broad elongated triangular penis in Pseudamnicola).

\section{Kaskakia khorrasanensis sp. n.}

urn:lsid:zoobank.org:act:8EDD45AD-46F2-4BC8-A7BE-73B44BBCDF6D

http://species-id.net/wiki/Kaskakia_khorrasanensis

Figs $10 \mathrm{a}-\mathrm{d}$

Type locality. Khorrasan Province, Kaskak stream in Kaskak village, 59 $10^{\prime} \mathrm{E}, 35^{\circ} 25^{\prime} \mathrm{N}$, ca. $1800 \mathrm{~m}$ asl., 11 June 2005.

Holotype (ZMH 79372): Shell height $2.5 \mathrm{~mm}$, width $1.9 \mathrm{~mm}$.

Paratypes (ZMH 79373): 21 ex. from type locality.

Etymology. Named for its occurrence in Khorrasan Province.

Description. The yellowish shell is conical to globular with 5.5 whorls, which are slightly convex and separated by a clear suture (Fig. 10a). The whorls increase rapidly with a prominent body whorl. The surface is glossy and finely striated. The apex is acute, the aperture is ovate and angled at the top, the umbilicus is closed. Shell height 2.3-2.5 mm, width $1.8-1.9 \mathrm{~mm}$.

Animal. The mantle and head are black. The penis is broad at the basis and tapered at the distal end (Figs 10b-d).

Differentiating features. As for the genus.

Distribution. Iran: Khorrasan Province; known only from type locality. 


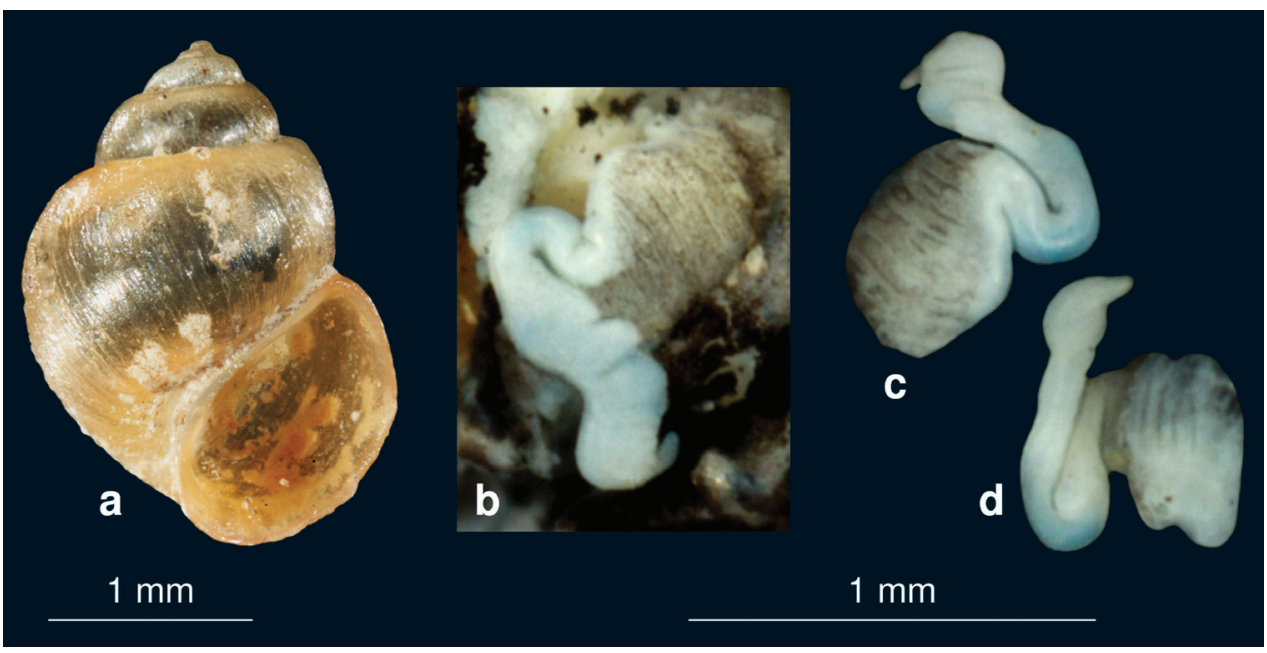

Figure 10. Kaskakia khorrasanensis sp. n. a shell b penis in situ c-d penis (c: dorsal view, d: ventral view).

\section{Genus Sarkhia gen. n.}

urn:lsid:zoobank.org:act:4AC287DC-4E88-4043-BA17-880E84883276

http://species-id.net/wiki/Sarkhia

Diagnosis. Shell elongated conical. Penis simple, broad at the basis and tapered at the distal end, with a black pigmentation mark. The tentacles are cylindrical.

Type species. Sarkia sarabensis sp. n.

Etymology. Named after the region where the species was collected.

Differential diagnosis. The genus seems to be closely related to Pseudamnicola (in the following, in parentheses), but the unique morphology of the penis, broad at the basis and tapered at the distal end (Figs 10b-c), with a black pigmentation mark (vs. broad and elongated triangular penis), and the presence of broad cylindrical tentacles (slim cylindrical tentacles) will separate the new genus from Pseudamnicola.

\section{Sarkhia sarabensis sp. n.}

urn:Isid:zoobank.org:act:F7FBD536-0970-4B9B-A0AC-EAF9E7C91C72 http://species-id.net/wiki/Sarkhia_sarabensis

Fig. $11 \mathrm{a}-\mathrm{c}$

Type locality. Kermanshah Province, Sarabe-Sahne (= Sarabe - bede - Sarkh) city, stream, 27 June 2005.

Holotype (ZMH 79374): Shell height $5.9 \mathrm{~mm}$, width $2.3 \mathrm{~mm}$.

Paratypes (ZMH 79375): 1 specimen dissected. 


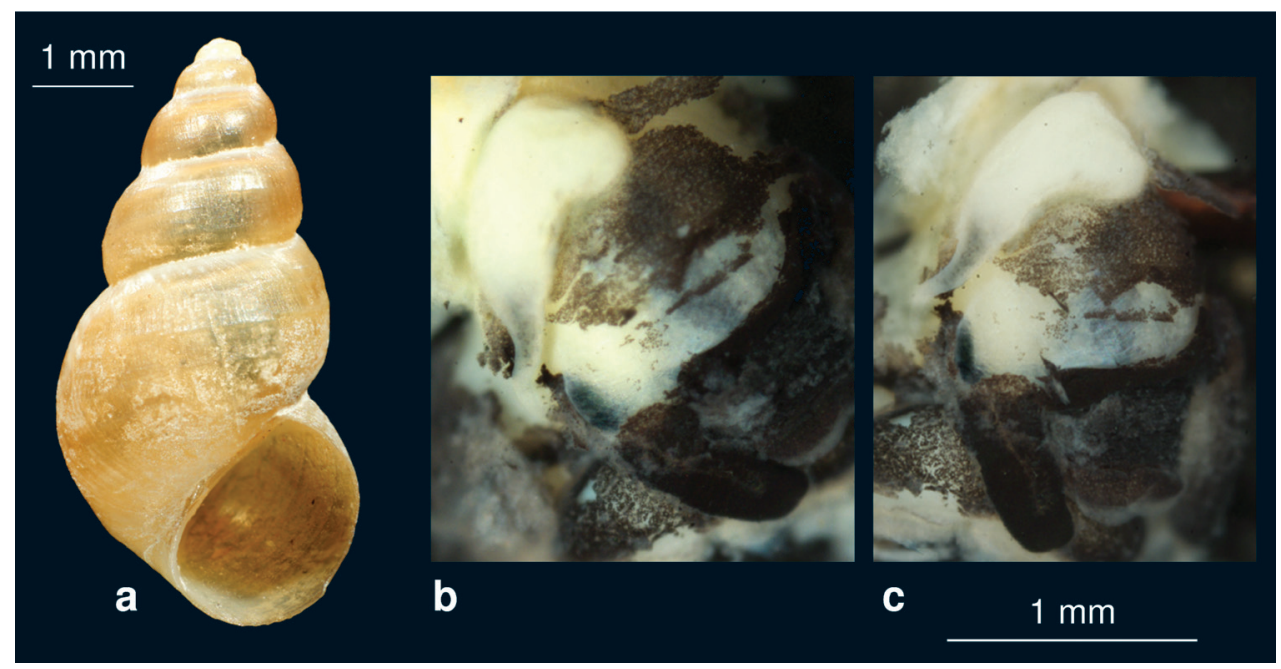

Figure I I. Sarkhia sarabensis nov. sp. a shell b, c penis in situ.

Etymology. Named after the region where the species was collected.

Description. The yellowish shell is elongated conical with 6.5 whorls, which are slightly convex and separated by a deep suture. The aperture is oval with a sharp periostome, the umbilicus is closed. The surface is dull. Shell height $5.9 \mathrm{~mm}$, width $2.3 \mathrm{~mm}$.

Differentiating features. The slim elongated conical shell with more than 5 whorls (Fig. 11a) is characteristic and separates this species from Sarkhia kermanshahensis (see below).

Distribution. Iran, Kermanshah Province; only known from type locality.

Sarkhia kermanshahensis (Glöer \& Pešić, 2009), comb. n.

http://species-id.net/wiki/Sarkhia_kermanshahensis

Fig. $12 \mathrm{~g}$

Pseudamnicola kermanshahensis Glöer \& Pešić, 2009 (synonymy)

New records. Markazi Province: IR51 [2 ex.].

Records from Iran. Kermanshah Province (as Pseudamnicola kermanshahensis Glöer and Pešić 2009).

Remarks. This species has originally been placed in the genus Pseudamnicola. However, due to the characteristic shape of the penis and the tentacles it is transfered to Sarkhia gen. n.

Distribution. Iran; Kermanshah and Markazi Provinces. 


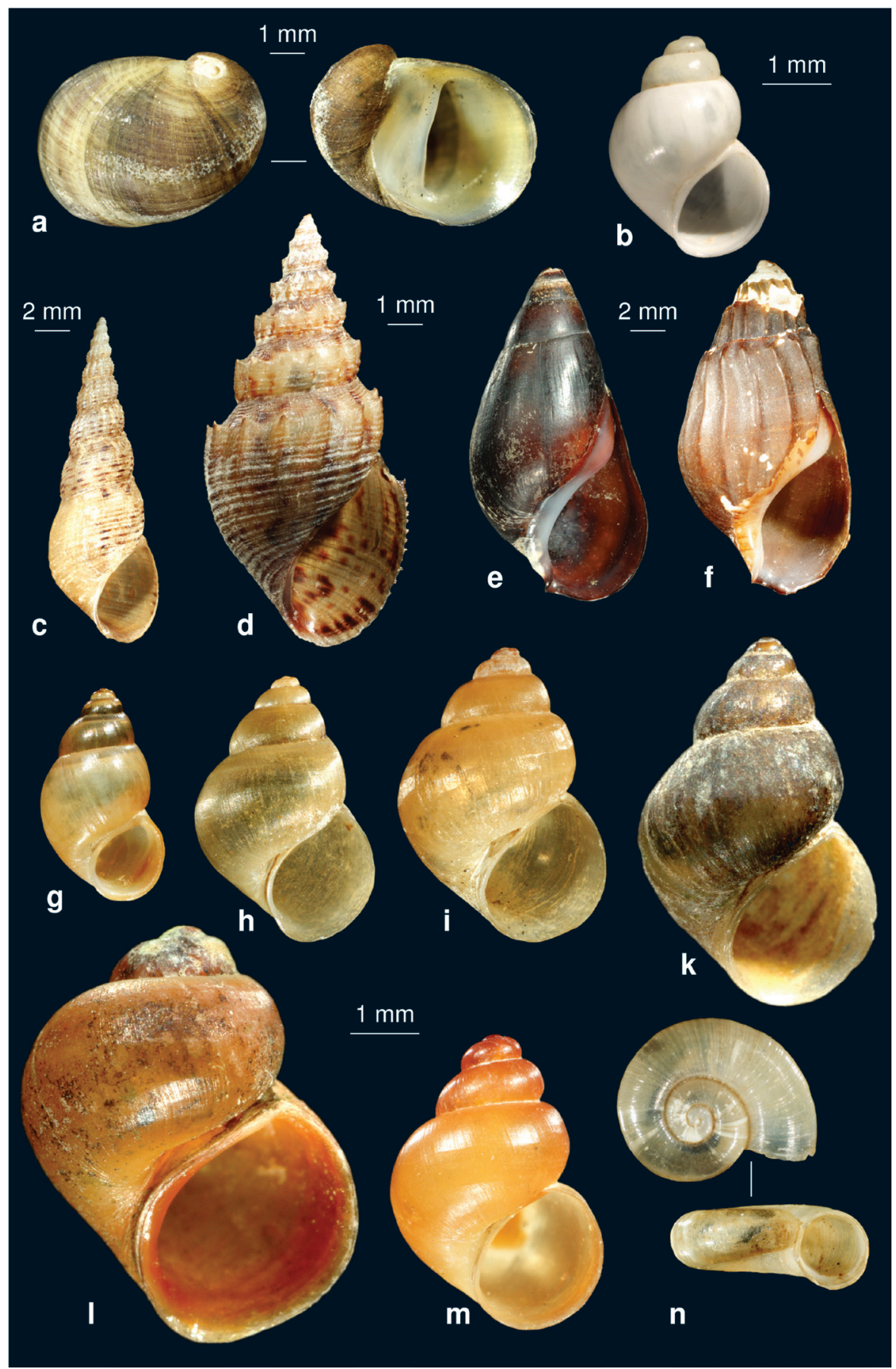

Figure 12. The prosobranch molluscs of Iran. a Theodoxus fluviatilis (operculum see Fig. 3d) b Bithynia (Bithynia) ejecta (syntype ZMZ 524006, Iraq, Samava, ex coll. Mousson, photo: E. Neubert) c Melanoides tuberculatus $\mathbf{d}$ Thiara scabra e Melanopsis sp. $\mathbf{f}$ Melanopsis costata $\mathbf{g}$ Farsithyra farsensis $\mathbf{h}$ Sarkhia kermanshahensis, i: Pseudamnicola saboori $\mathbf{k}$ P. zagrosensis I Pseudobithynia irana $\mathbf{m}$ P. zagrosia $\mathbf{n}$ Valvata cristata. 


\section{Genus Belgrandiella Wagner, 1927}

Type species. Belgrandia kusceri Wagner, 1914

Belgrandiella elburensis (Starmühlner \& Edlauer, 1957), comb. n. http://species-id.net/wiki/Belgrandiella_elburensis

Records from Iran. Tehran Province - “Frauenfeldia elburensis” Starmühlner and Edlauer (1957).

Remarks. Starmühlner and Edlauer (1957) originally described this species as Frauenfeldia elburensis. However, the genus name Frauenfeldia is preoccupied, and thus, the species of this genus have been re-assigned to Belgrandiella, Boleana, Graziana and Sarajana (Radoman 1983). Due to the shape of the aperture in original description (see Starmühlner and Edlauer 1957) we affiliate this species to the genus Belgrandiella.

Distribution. Iran, only known from the locus typicus (Gelandoah, $60 \mathrm{~km} \mathrm{NE}$ of Tehran).

\section{Genus Hauffenia (Pollonera, 1898)}

Type species. Valvata erythropomatia Hauffen, 1856

\section{Hauffenia erythropomatia (Hauffen, 1856)}

http://species-id.net/wiki/Hauffenia_erythropomatia

Records from Iran. Sistan and Baluchestan Province (Source lake Gomun) - "Erythropomatiana erythropomatia" Starmühlner and Edlauer (1957).

Remarks. Most probably, Starmühlner and Edlauer (1957) misidentified this subterranean species, known only from its type locality in Slovenia, far away from Iran. The comparison with the description of H. erythropomatia by Radoman (1983) shows that these species are not conspecific as the umbilicus seems to be broader in later species compared with the species depicted by Starmühlner and Edlauer (1957). Unfortunately this species could not be found in Edlauer's collection in NHMW (Anita Eschner, pers. comm.). The record for this species is kept until specimens from the original locality could be studied.

\section{Family Stenothyridae Tryon, 1866}

\section{Genus Stenothyra Benson, 1854}

Type species. Nematura deltae Benson, 1836 
Stenothyra arabica Neubert, 1998

http://species-id.net/wiki/Stenothyra_arabica

Records from Iran. Hormozgan Province (Ghasemi et al. 2011).

Distribution. Saudi-Arabia, Iran.

\section{Genus Gangetia Ancey, 1890}

Type species. Hydrobia (Belgrandia) miliacea Nevill, 1880

\section{Gangetia (Iranothyra) uzielliana (Issel, 1866)}

http://species-id.net/wiki/Gangetia_uzielliana

Records from Iran. Kerman province (as Bythinia uzielliana: Issel 1866, Martens 1874), as Hydrobia uzielliana: Biggs (1936, 1937), (as Pseudamnicola uzelliana: Starmühlner and Edlauer (1957), (as Pseudamnicola uzelliana: Starmühlner (1961, 1965); Fars province (as Pseudamnicola uzelliana: Starmühlner and Edlauer (1957), (as Pseudamnicola uzelliana: Starmühlner and Edlauer (1961, 1965).

Rejected records. Yazd Province (as Pseudamnicola uzelliana: Starmühlner and Edlauer 1957).

Remarks. Schütt (1973) classified this species in the genus Gangetia and introduced the new subgenus Iranothyra Schütt, 1973. Mansoorian (1994) reported Gangetia uzielliana with some doubts. However, his species clearly differs from the topotype of Gangetia uzielliana illustrated by Schütt (1973). Most probably, the species recorded by Mansoorian (1994) under this name represents an undescribed new species (Glöer and Pešíc 2009).

Distribution. Iran.

\section{Genus Farsithyra Glöer \& Pešić, 2009}

Type species. Farsithyra farsensis Glöer \& Pešić, 2009

\section{Farsithyra farsensis Glöer \& Pešić, 2009}

http://species-id.net/wiki/Farsithyra_farsensis

Fig. 12f, 13a-b

Bulimus badiella: Starmühlner and Edlauer 1957, non badiella Küster, 1852 (synonymy)

Records from Iran. Fars Province (Glöer and Pešić 2009). 


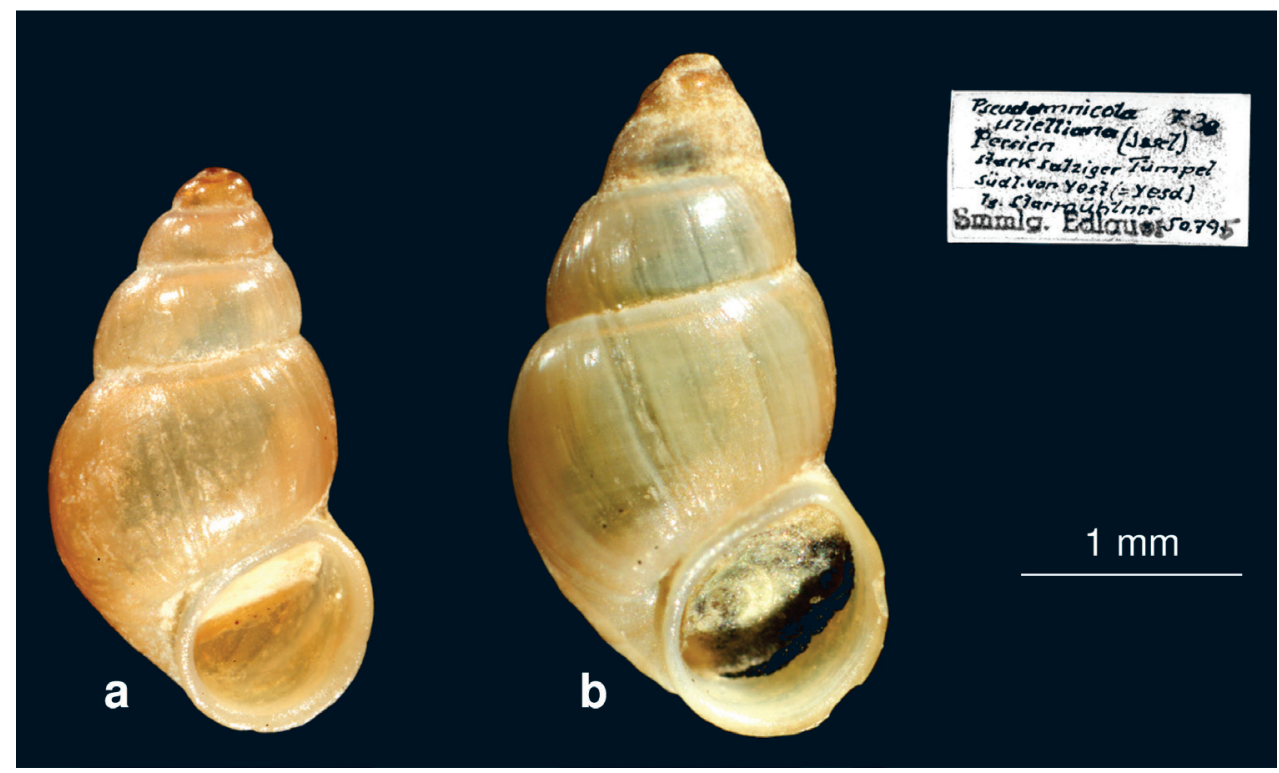

Figure 13. Farsithyra farsensis (from Edlauer's collection, NHMW "Pseudamnicola uzielliana" 75000/E/50795): a-b shell.

New records. Hormozgan Province: IR17-11 [1 ex.].

Material examined. NHMW "Pseudamnicola uzelliana Issel", Persien, stark salziger Tümpel, südl.von Yest (=Yesd), leg. Starmühlner. NHMW 60.459 "Bulimus badiella“, Lake Taschk, 07.07.1956 leg. Löffler.

Associated species. Melanoides tuberculatus, Melanopsis sp., Melanopsis doriae, Thiara scabra.

Remarks. Starmühlner and Edlauer (1957) mentioned Gangetia uzielliana from many sampling sites in Yazd Province. An analysis of one lot from the Edlauer collection (NHMW) with the specimens from Yazd Province shows that these specimens (Fig. 13a-b) belong to Farsithyra farsensis. Further, re-examination of the specimens from Lake Taschk in Fars Province identified by Starmühlner and Edlauer (1957) as Bulimus badiella (syn. to Bithynia badiella) shows that it is also conspecific with Farsithyra farsensis.

Distribution. Iran: Fars, Yazd and Hormozgan Provinces.

Family Valvatidae J.E. Gray, 1840

Genus Valvata O.F. Müller, 1773

Type species. Valvata cristata O.F. Müller, 1774 
Valvata cristata O.F. Müller, 1774

http://species-id.net/wiki/Valvata_cristata

Fig. $12 \mathrm{~m}$

New records. Mazandaran Province: IR01-05 [6 ex.]. Tehran Province: IR48-05 [2 ex.]. Associated species. Bithynia mazandaranensis sp. n., Planorbis carinatus, Anisus sp., Valvata nowshahrensis sp. n., Hippeutis complanatus.

Records from Iran. Mansoorian (1994).

Remarks. Considering the photo provided by Mansoorian (1994), he probably confused this species with Valvata nowshahrensis sp. n. (see below).

Distribution. Palaearctic.

Valvata piscinalis O.F. Müller, 1774

http://species-id.net/wiki/Valvata_piscinalis

Records from Iran. Gilan, Mazandaran and Lorestan Province - Mansoorian (2000).

Distribution. Palaearctic.

Valvata nowshahrensis sp. $\mathbf{n}$.

urn:Isid:zoobank.org:act:944E6EE3-B23C-43FB-A305-882A4D4CF3D9

http://species-id.net/wiki/Valvata_nowshahrensis

Fig. $14 \mathrm{a}-\mathrm{c}$

Type locality. Mazandaran Province, Nowshahr city, pond near the Caspian See, $51^{\circ} 31^{\prime} \mathrm{E}, 36^{\circ} 38^{\prime} \mathrm{N}, 18$ June 2005.

Holotype (ZMH 79376): Shell diameter $3.3 \mathrm{~mm}$, height $2.3 \mathrm{~mm}$.

Paratypes (ZMH 79377): 2 specimens from type locality; [2 ex.], Kermanshah Province: IR105-05.

Etymology. Named after the region, where the species was collected.

Description. The yellowish shell is translucent with 3 circular whorls. The umbilicus is wide, and the first whorl is visible through the umbilicus. The surface is glossy with very fine ribs. Shell diameter $3.2-3.3 \mathrm{~mm}$, height $2.3 \mathrm{~mm}$.

Differentiating features. The new species can be distinguished from Valvata piscinalis by its larger umbilicus and from $V$. cristata by its higher spire.

Remarks. This species has possibly been depicted by Mansoorian (1994) and confused with Valvata cristata.

Associated species. Pseudobithynia mazandaranensis sp. n., Planorbis carinatus, Anisus sp., Valvata cristata, Hippeutis complanatus

Distribution. Iran: Mazandaran and Kermanshah Provinces. 


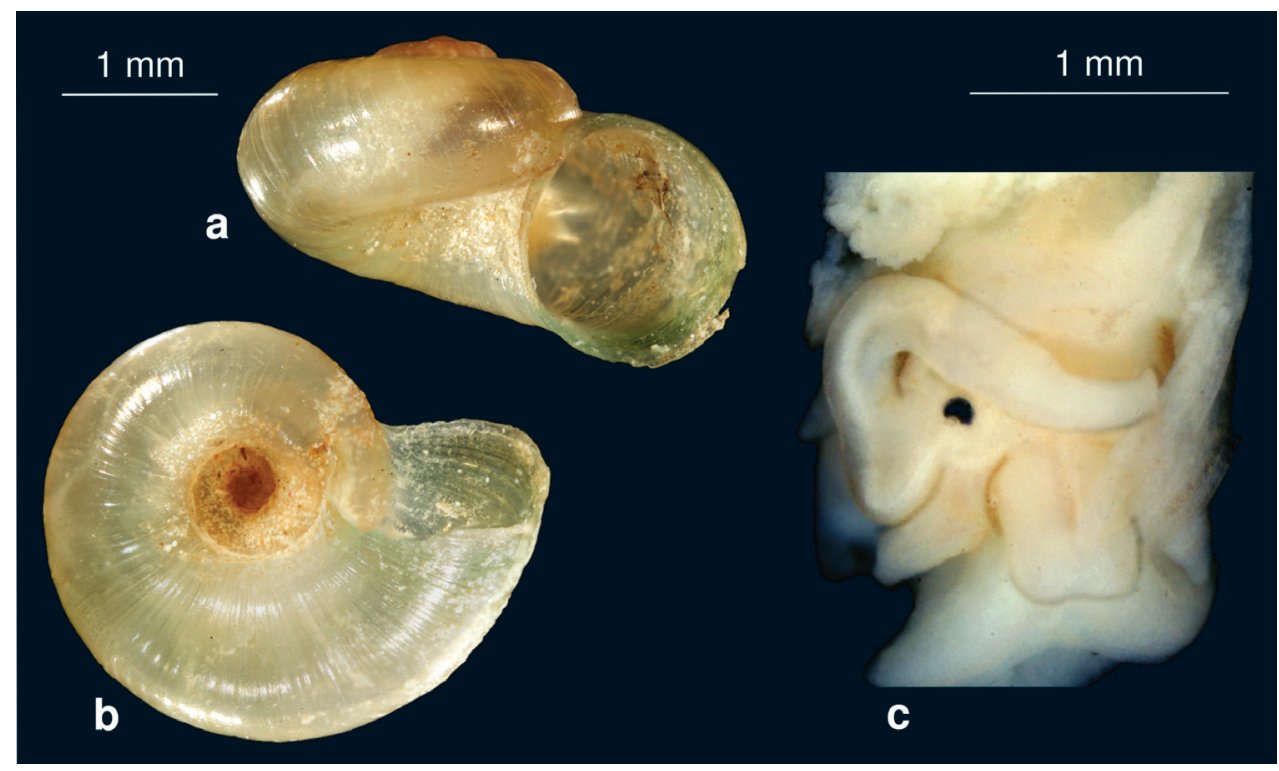

Figure 14. Valvata nowshahrensis sp. $\mathrm{n}$. a shell $\mathbf{b}$ ventral view on the umbilicus $\mathbf{c}$ head with penis in situ.

\section{Pulmonata}

Family Acroloxidae Thiele, 1931

Genus Acroloxus H. Beck, 1838

Type species. Patella lacustris Linnaeus, 1758

Acroloxus lacustris (Linnaeus, 1758)

http://species-id.net/wiki/Acroloxus_lacustris

Rejected Records from Iran. Mazandaran Province - Forcart (1935).

Remarks. See remarks under Acroloxus pseudolacustris sp. n.

\section{Acroloxus pseudolacustris sp. n.}

urn:lsid:zoobank.org:act:83575F59-E417-44D3-8F6D-A5DB45EA2B21

http://species-id.net/wiki/Acroloxus_pseudolacustris

Fig. 15a-b

Type locality. Gilan Province, IR82-05, Bandar Anzali Lagoon, 49²7'E, 37²6'N, 16 June 2008.

Holotype (ZMH 79378): Shell length $4.0 \mathrm{~mm}$, width $2.0 \mathrm{~mm}$, height $0.9 \mathrm{~mm}$.

Paratypes. 2 ex., NMB 11516a “Acroloxus lacustris" zwischen Nika und Aschref, 10 m ü. M., Drs. A. Erni \& R. Buxtorf leg. 22.X.1931. 


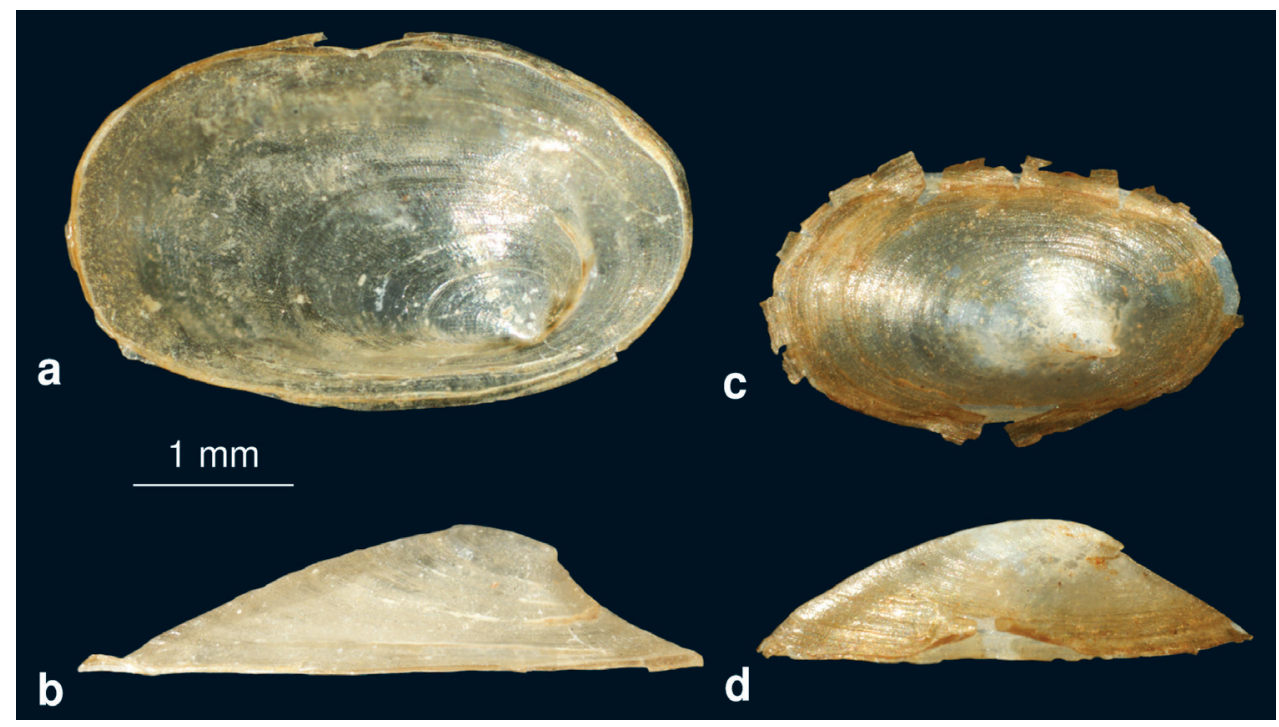

Figure I5. a-b Acroloxus pseudolacustris sp. n.: shell c-d Acroloxus lacustris (from Hamburg, Germany): shell.

Etymology. Named for its resemblance with Acroloxus lacustris.

Description. The oval limpet shell is transparent. The apex is blunt and bent to the left side (Figs 15a-b).

Differentiating features. The new species resembles $A$. lacustris, which can be easily distinguished by the shape of apex, which is always acute and not blunt (Figs $15 \mathrm{c}-\mathrm{d})$ like in the new species. From Russia, no Acroloxus sp. with a blunt apex is known (Vinarski, pers. comm.).

Remark. An analysis of the two specimens from Forcart's collection (NMB 11516a) identified as Acroloxus lacustris from Mazandaran Province shows that these specimens belong to $A$. pseudolacustris sp. n.

Associated species. Haitia acuta.

Distribution. Iran: Gilan and Mazandaran Provinces.

\section{Family Lymnaeidae Rafinesque, 1815}

\section{Genus Radix Montfort, 1810}

http://species-id.net/wiki/Radix

Type species. Helix auricularia Linnaeus, 1758

Remarks. Hubendick (1951) grouped most Radix spp. from the Near East (i.e. $R$. tenera, $R$. euphratica - "Mesopotamia», $R$. bactriana - Afghanistan, R. gedrosiana - Iran, $R$. rectilabrum - Seistan and Baluchistan, $R$. persica - Iran and $R$. acuminata - (Bengal, India) under the palaearctic $R$. auricularia, but from Europe he lumped all Radix spp. 
together in three species. Today, five Radix species are known from Europe, confirmed by molecular (Pfenninger et al. 2006, Schniebs et al. 2011) and anatomical studies (Glöer 2002). Only a few species can be distinguished by the shells alone (e.g. Radix ampla, $R$. auricularia). Most species show a large morphological plasticity in the shape of the shell, so this character cannot be used for distinguishing species. Ananndale and Prashad (1919) and Annandale and Rao (1923) provided anatomical data of Radix spp., but these drawings are not suitable enough to identify the Radix spp. found by us in Iran. The diagnostic features and taxonomic relationship of the Iranian Radix species require further revision and particularly the application of molecular techniques with topotypes of the species. The following list of Radix species contains the hitherto recorded nominal species, their taxonomic status remains to be explored.

\section{Radix persica (Issel, 1865)}

http://species-id.net/wiki/Radix_persica

Fig. 16a

Records from Iran. Kerman Province - "Limnaea auricularia var. persica” Issel (1865), "Limnaea auricularia var. persica" Martens (1874); Seistan and Baluchestan Province (as Limnaea auricularia var. persica: Annandale and Prashad 1919); Isfahan Province (as Lymnaea persica: Biggs 1937).

New records. Markazi Province: IR27-07 [7 ex.]

Distribution. South Iran.

Radix auricularia (Linnaeus, 1758)

http://species-id.net/wiki/Radix_auricularia

Records from Iran. Khuzestan Province (Mansoorian 2001); Mazandaran, Gilan and Lorestan Provinces (Starmühlner and Edlauer 1957), Isfahan Province (Starmühlner 1965).

Distribution. Palaearctic.

Radix bactriana (Annandale \& Prashad, 1919)

http://species-id.net/wiki/Radix_bactriana

Figs $16 \mathrm{~b}-\mathrm{d}$

Records from Iran. Seistan and Baluchestan Province (Annandale and Prashad 1919); Kerman Province (Starmühlner and Edlauer 1957).

New records. Markazi Province: IR03-05 [1 ex], IR87-05 [9 ex.], IR88-05 [3 ex.], IR89-05 [2 ex], IR91-05 [3 ex.]; Khorasan Province: IR67-05 [1 ex.], IR79-05 [1 ex.].

Distribution. Iran: Seistan and Baluchestan and Kerman Provinces. 
Radix iranica (Annandale \& Prashad, 1919)

http://species-id.net/wiki/Radix_iranica

Fig. $16 \mathrm{~g}$

Records from Iran. Seistan and Baluchestan Province (Annandale and Prashad 1919).

New records. Markazi Province: IR89-05 [5 ex].

Distribution. Iran: Seistan and Baluchestan Province.

Radix gedrosiana gedrosiana (Annandale \& Prashad, 1919)

http://species-id.net/wiki/Radix_gedrosiana_gedrosiana

Records from Iran. Seistan and Baluchistan Province (Annandale and Prashad 1919), Azarbayjan Province (Starmühlner and Edlauer 1957), Khuzestan Province (Chu et al. 1968, Massoud and Hedayeti-Far 1979, as Lymnaea auricularia gedrosiana: Mansoorian 2001), N Iran (Annandale 2000).

Distribution. Iran, Pakistan.

Radix gedrosiana rectilabrum (Annandale \& Prashad, 1919)

http://species-id.net/wiki/Radix_gedrosiana_rectilabrum

Records from Iran. Seistan and Baluchestan Province (Annandale and Prashad 1919); Isfahan Province (Starmühlner and Edlauer 1957).

Distribution. Iran; endemic.

Radix hordeum (Mousson, 1874)

http://species-id.net/wiki/Radix_hordeum

Records from Iran. Seistan and Baluchestan Province (Annandale and Prashad 1919)

Distribution. Iraq (Euphrates, as Limnaea hordea: Mousson 1874); Iran: Seistan and Baluchestan Province.

Radix lagotis (Schrank, 1803)

http://species-id.net/wiki/Radix_lagotis

Records from Iran. Qom, Tehran and Gilan Provinces (Martens 1874); Kerman Province (Biggs 1937).

Remarks. This species has been described from the Danube (Germany) and most probably does not occur in Iran. According to Subba Rao (1989) $R$. lagotis is a synonym of $R$. peregra (syn. to $R$. labiata). However, recently Schniebs et al. (2011) clearly showed that $R$. lagotis and $R$. labiata are distinct species.

Distribution. Europe. 

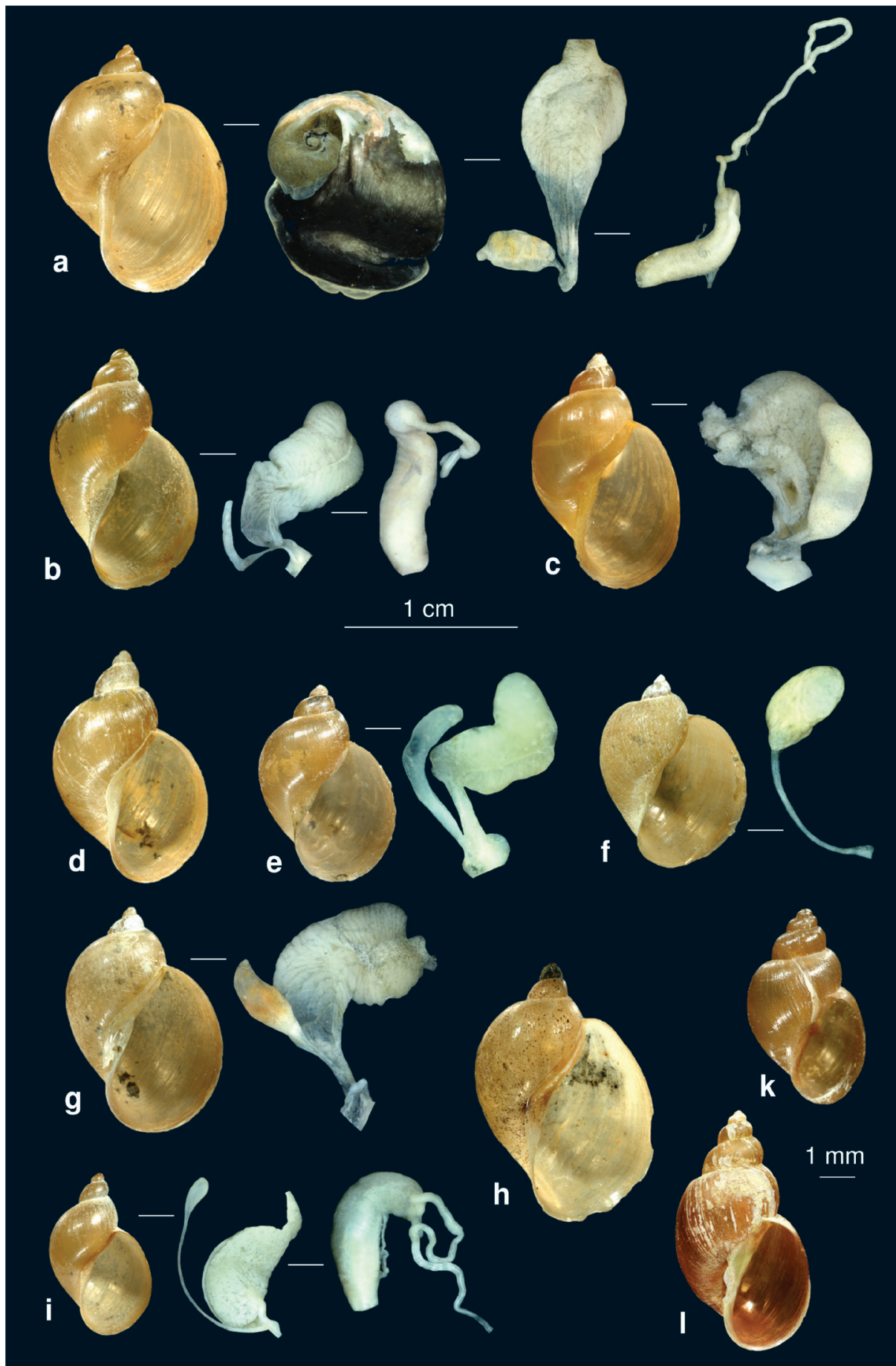

Figure 16. The Lymnaeidae of Iran. a Radix persica (IR27-07) b-d Radix bactriana (b IR03-05 c IR8705 d IR88-05 e IR91-05) f Radix persica (IR107-05) g Radix iranica (IR89-05) h Radix sp. i Radix sp. k Galba truncatula (IR62-05) I Galba schirazensis. 
Radix labiata (Rossmaessler, 1835)

http://species-id.net/wiki/Radix_labiata

Records from Iran. (mentioned as $R$. peregra f. canalifera): N Iran (Caspian Sea) (Eliazian et al. 1979); Kerman Province (Starmühlner and Edlauer (1957); Fars Province (Starmühlner and Edlauer 1957); Yazd Province (Starmühlner and Edlauer 1957); Kermanshah Province (Starmühlner and Edlauer 1957), Starmühlner (1965).

Remarks. $R$. labiata is a species which prefers springs and is distributed in $\mathrm{M}$ - and $S$ Europe and the Balkans (Glöer 2002).

Distribution. Europe.

\section{Genus Galba Schrank, 1803}

Type species. Galba truncatula O.F. Müller, 1774

\section{Galba truncatula (O.F. Müller, 1774)}

http://species-id.net/wiki/Galba_truncatula

Fig. $16 \mathrm{k}$

Records from Iran. Seistan and Baluchestan Province (as Limnaea truncatula: Annandale and Prashad 1919); North Iran (Caspian Sea) (as Lymnaea truncatula: Eliazian et al. 1979); Manzandaran Province (Forcart 1935); Gilan, Mazandaran and Lorestan Province (Mansoorian 2000); Kerman Province (Starmühlner and Edlauer 1957, Biggs 1937); Tehran Province (Starmühlner and Edlauer 1957); Khuzestan Province (Mansoorian 2001, Chu et al. 1968, Massoud and Hedayeti-Far 1979); Isfahan Province (Biggs 1937); Semnan Province (Starmühlner 1961); Hormozgan Province (Starmühlner 1965).

New records. Khorasan Province: IR63-05 [22 ex.]; IR66a-05 [1 ex.]; IR77-05 [1 ex.].

Associated species. Radix sp., Planorbis intermixtus, Physella acuta.

Distribution. Worldwide.

\section{Galba schirazensis Küster, 1862}

http://species-id.net/wiki/Galba_schirazensis

Fig. 161

Records from Iran. Fars Province (Küster 1862); Gilan Province (Bargues et al. 2010).

Distribution. Iran, Mediterranean, Central America (Bargues et al. 2011). 


\section{Genus Stagnicola Jeffreys, 1830}

Type species. Buccinum palustre O.F. Müller, 1774

\section{Stagnicola palustris (O.F. Müller, 1774)}

http://species-id.net/wiki/Stagnicola_palustris

Records from Iran. Kerman Province (Martens 1874); Isfahan Province (Martens 1874); Qazvin and E Azarbayjan Provinces (Starmühlner and Edlauer 1957); Gilan, Mazandaran and Lorestan Provinces (Eliazian et al. 1979); N Iran (Mansoorian 2000).

Rejected Records from Iran. Mazandaran Province (Forcart 1935).

Remark. The recent insights on the distribution of Stagnicola palustris show that it is a Northern European/Siberian species. Most probably, the species reported from Iran as $S$. palustris represents an undescribed species (see below).

\section{Stagnicola sp.}

Fig. 17

Records from Iran. Mazandaran Province (Forcart 1935 ).

Material examined: 35 ex., NMB 11518b "Stagnicola palustris" Zw. Nika und Aschref, Dr. Erni \& Buxtorf 1934; 3 ex., NMB 11518a "Iran, Prov. Mazandaran. Meschhediser, Geniste am rechten Ufer des Babul ca. 300 m S der Mündung, -26 m Meereshöhe. Leg. 23.8.1931 \& don. 1935 Drs. A. Erni \& R. Buxtorf”.

Remark. An examination of the specimens from NMB identified by Forcart (1935) as Stagnicola palustris shows that these specimens are not conspecific with $S$. palustris. Namely, Forcart's specimens clearly differ in the aperture, which is broader at the basis (Fig. 17) than in S. palustris. However, due to the fact that the shells of Stagnicola spp. are very variable, it is not possible to identify or eventually describe this specis as new to science without anatomical studies.

Genus Lymnaea Lamarck, 1799

Type species. Lymnaea stagnalis (Linnaeus, 1758)

Lymnaea stagnalis (Linnaeus, 1758)

http://species-id.net/wiki/Lymnaea_stagnalis

Records from Iran. Khuzestan Province (Mansoorian 1998, 2001).

Distribution. Palaearctic. 


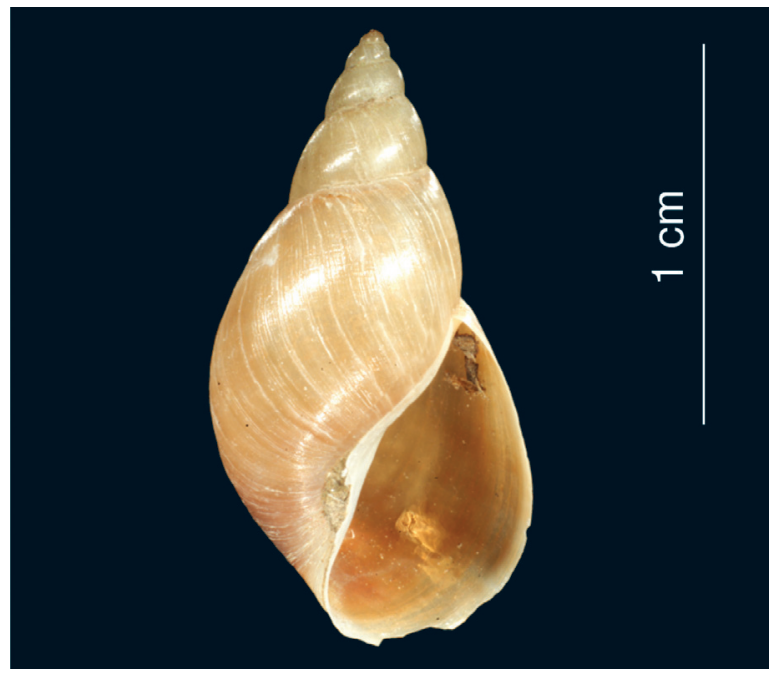

Figure I7. Stagnicola sp. (from Forcart's collection, NMB 11518b “Stagnicola palustris”): shell.

Family Planorbidae Rafinesque, 1815

Genus Bulinus O.F. Müller, 1781

Type species. Physa truncata Audouin, 1827

Bulinus truncatus (Audouin, 1827)

http://species-id.net/wiki/Bulinus_truncatus

Records from Iran. Khuzestan Province (Chu et al. 1968, Massoud and Hedayeti-Far 1979, Mansoorian 1994, 2001); Gilan Province (Mansoorian 2000).

Distribution. Tropical Africa, Arabian Peninsula, Iran.

\section{Genus Planorbis O.F. Müller, 1774}

Type species. Helix planorbis Linnaeus, 1758

\section{Planorbis intermixtus Mousson, 1874}

http://species-id.net/wiki/Planorbis_intermixtus

Fig. 18b

Planorbis subangulatus Philippi, 1844; Planorbis persicus Ancey, 1900 (synonymy)

Records from Iran. Northern Iran (as P. planorbis: Mansoorian 2000); Mazandaran Province (as P. planorbis: Eliazian et al. 1979, Mansoorian 2000); Fars Province (as 
P. planorbis: Forcart 1935, Starmühlner and Edlauer 1957); Isfahan Province (Glöer and Pešić 2010); Yazd Province (as P. persicus, P. subangulatus: Biggs 1937, 1971, Starmühlner and Edlauer 1957); Gilan Province (as Anisus (Gyraulus) intermixtus: Starmühlner and Edlauer 1957); Khuzestan Province (as P. planorbis, P. planorbis submarginatus: Starmühlner and Edlauer 1957, as P. planorbis: Biggs 1971); Markazi Province (Chu et al. 1968, Massoud and Hedayeti-Far 1979, Mansoorian 2001, Glöer and Pešić 2010).

New records. Mazandaran Province: IR01-05 [11 ex.]; Markazi Province: IR5105 [11 ex.]; IR87-05 [3 ex.]; IR88-05 [7 ex.]; IR91-05 [5 ex.]; IR93-05 [1 ex.]; Khorasan Province: IR66-05 [10 ex.]; IR67-05 [2 ex.]; IR68-05 [5 ex.]; IR78a-05 [2 ex.]; IR78b-05 [7 ex.]; Fars Province: IR02-07 [2 ex.]; IR07-07 [2 ex.]; IR26-07 [9 ex.]; IR27-07 [3 ex.].

Associated species. Physella acuta, Pseudobithynia zagrosia, Radix sp.

Remarks. The species Planorbis planorbis and P. intermixtus can only be distinguished by the number of prostate diverticula (Glöer and Pešić 20го). All Planorbis spp. collected in Iran have been anatomically studied and no P. planorbis could be found. Thus we list the old records from Iran under $P$. intermixtus.

In addition, Planorbis subangulatus Philippi, 1844 and Planorbis persicus Ancey, 1900 have been mentioned from Iran (Ancey 1900, Biggs 1937). Both species have been described on the basis of the shells, the morphology of which falls within variability of $P$. intermixtus. Thus we list these species under $P$. intermixtus.

Distribution. Turkey, Iran, N India.

\section{Planorbis carinatus O.F. Müller, 1774}

http://species-id.net/wiki/Planorbis_carinatus

Fig. 18a

Records from Iran. Northern Iran (Mansoorian 1994).

New records. Mazandaran Province: IR01-05 [5 ex., anat. det. ].

Associated species. Valvata cristata, Anisus sp., Valvata nowshahrensis sp. n., Pseudobithynia mazandaranensis sp. n., Hippeutis complanatus.

Distribution. Palaearctic.

Genus Anisus S. Studer, 1820

http://species-id.net/wiki/Anisus

Type species. Helix spirorbis Linnaeus, 1758

Remarks. The identification of the species of this genus is based on the anatomical features (Glöer and Meier-Brook 2008), so all former records of this genus are questionable and need new confirmation. 


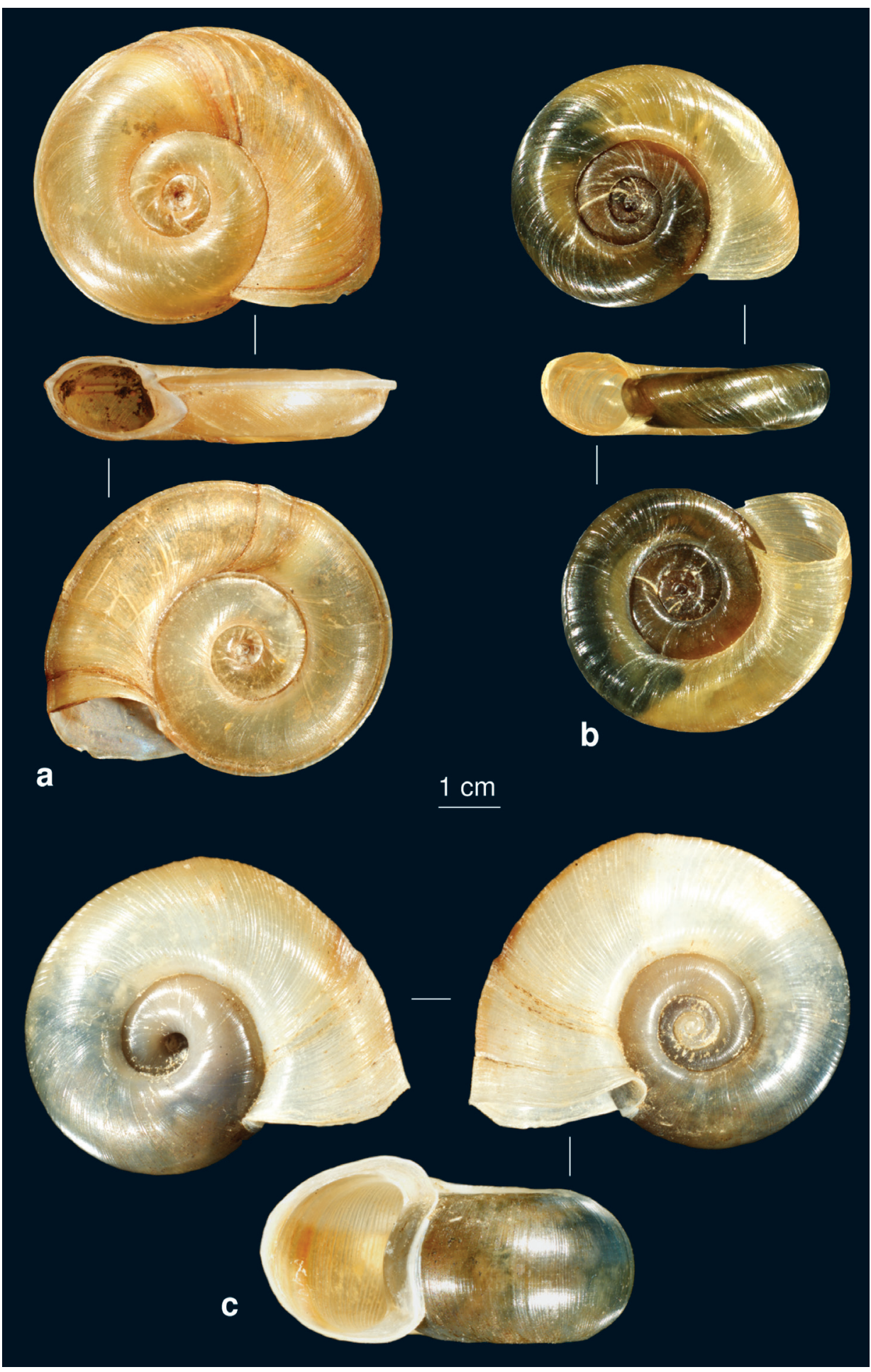

Figure 18. The Planorbis spp. of Iran. a Planorbis carinatus b Planorbis intermixtus c Indoplanorbis exustus. 
Anisus leucostoma (Millet, 1813)

http://species-id.net/wiki/Anisus_leucostoma

Records from Iran. Gilan Province - Mansoorian (1994, 2000).

Distribution. Palaearctic.

Anisus spirorbis (Linnaeus, 1758)

http://species-id.net/wiki/Anisus_spirorbis

Records from Iran. Azarbayjan Province (Starmühlner and Edlauer 1957)

Distribution. Palaearctic.

\section{Anisus sp.}

Fig. 19

New records. Mazandaran Province: IR01-05 [1 empty shell].

Associated species. Planorbis carinatus, Anisus sp., Valvata nowshahrensis sp. n., Pseudobithynia mazandaranensis sp. n., Hippeutis complanatus.

Remarks. The shells (Fig. 19) of this species are similar to the rare species Anisus vorticulus, which is distributed in Central and E Europe. Additional material is necessary to resolve the taxonomy of this taxon.

Anisus vortex (Linnaeus, 1758)

http://species-id.net/wiki/Anisus_vortex

Records from Iran. Fars Province - Mansoorian (1994).

Distribution. Euro-Siberian.

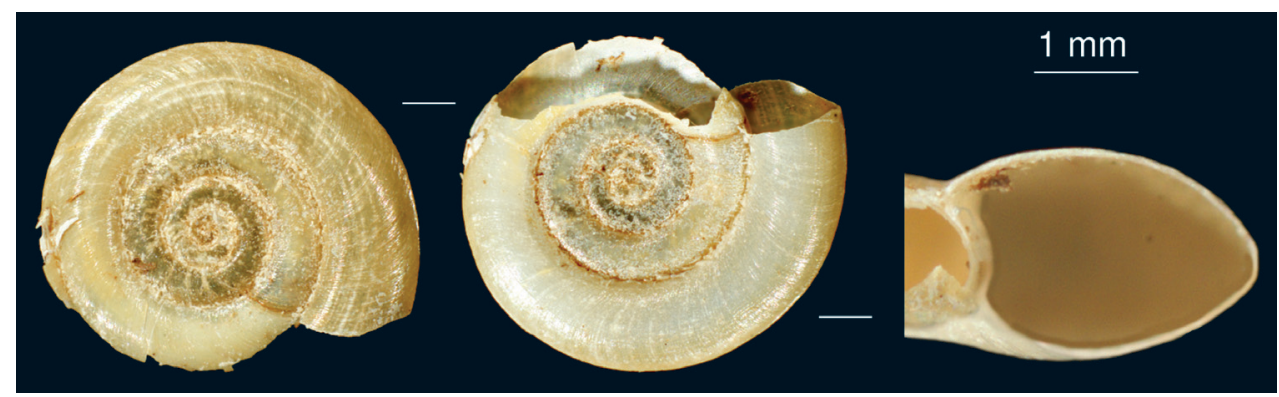

Figure 19. Anisus sp.: shell. 


\section{Genus Gyraulus Charpentier, 1837}

Type species. Planorbis albus O.F. Müller 1774

\section{Gyraulus piscinarum (Bourguignat, 1852)}

http://species-id.net/wiki/Gyraulus_piscinarum

Fig. 20b

Records from Iran. Tehran Province (as Anisus (Gyraulus) piscinarum: Starmühlner and Edlauer 1957).

New records. Mazandaran Province: IR02-05 [6 ex.]; Fars Province: IR07-07 [13 ex.]; Seistan and Baluchestan Province: IR08-11 [10 ex.], IR09-11 [14 ex.].

Distribution. Lebanon, Syria, Turkey (Black Sea coast), Iran.

Remark. The examined specimens have been identified by its anatomy and are in a good agreement with Glöer and Bößneck (2007) as well as the anatomical studies carried out by Meier-Brook (1983).

\section{Gyraulus euphraticus (Mousson, 1874)}

http://species-id.net/wiki/Gyraulus_euphraticus

Records from Iran. Seistan and Baluchestan Province (Annandale and Prashad 1919); Fars Province (Starmühlner and Edlauer 1957); Khuzestan Province (Massoud and Hedayeti-Far 1979, Mansoorian 2001).

Remarks. Gyraulus euphraticus can be confused with Anisus spp. (Glöer and Bössneck 2007).

Distribution. Irak, Iran.

\section{Gyraulus convexiusculus (Hutton, 1849)}

http://species-id.net/wiki/Gyraulus_convexiusculus

Fig. 20a

New records. Seistan and Baluchestan Province: IR08-05 [2 ex.]; IR09-11 [4 ex.].

Records from Iran. Seistan and Baluchestan Province (Annandale and Prashad 1919); Yazd Province (Starmühlner and Edlauer 1957).

Distribution. Afghanistan to Thailand, Iran.

\section{Gyraulus laevis (Alder, 1838)}

http://species-id.net/wiki/Gyraulus_laevis

Records from Iran. Mazandaran Province (Forcart 1935, Starmühlner and Edlauer 1957).

Distribution. Central Europe. 


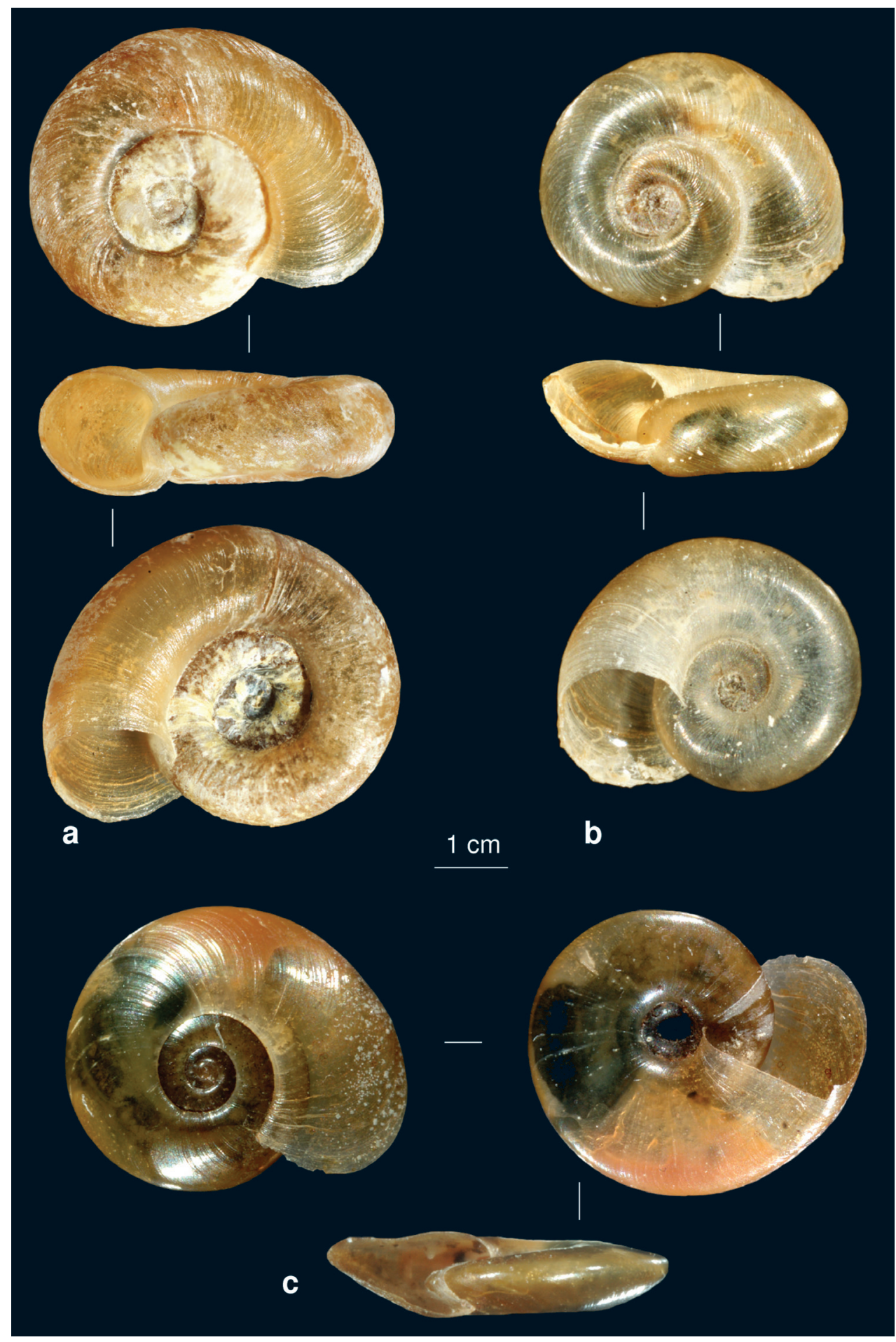

Figure 20. a Gyraulus convexiusculus b G. piscinarum c Hippeutis complanatus. 
Genus Indoplanorbis Annandale and Prashad, 1920

Type species. Planorbis exustus Deshayes, 1834

Indoplanorbis exustus (Deshayes, 1834)

http://species-id.net/wiki/Indoplanorbis_exustus

Fig. $18 \mathrm{c}$

Records from Iran. Seistan and Baluchestan Province (Mansoorian 1994).

New records. Hormozgan Province: IR15-11 [5 ex.].

Distribution. Iran, Oman, Yemen, India, Nepal, SE Asia.

Genus Hippeutis Charpentier, 1837

Type species. Helix complanata Linnaeus, 1758

Hippeutis complanatus (Linnaeus, 1758)

http://species-id.net/wiki/Hippeutis_complanatus

Fig. 20c

New records. Mazandaran Province: IR01-05 [3 ex., anat. det.].

Remarks. New for Iran.

Distribution. Europe to W Asia.

Genus Segmentina Fleming, 1818

Type species. Planorbis nitidus O.F. Müller, 1774

Segmentina calatha (Benson, 1850)

http://species-id.net/wiki/Segmentina_calatha

Records from Iran. Seistan and Baluchestan Province (Annandale and Prashad 1919).

Distribution. India, Iran.

Genus Ferrissia Walker, 1903

Type species. Ferrissia rivularis (Say, 1817) 
Ferrissia isseli (Bourguignat, 1866)

http://species-id.net/wiki/Ferrissia_isseli

Records from Iran. Gilan Province (as Protancylus (Ferrissia) isseli: Starmühlner and Edlauer 1957).

Distribution. Africa, Iran.

Family Physidae Fitzinger, 1833

Genus Haitia Clench \& Aguayo, 1932

Type species. Physa globosa Haldeman, 1841

\section{Haitia acuta (Draparnaud, 1805)}

http://species-id.net/wiki/Haitia_acuta

Records from Iran. all mentioned as Physa acuta: Gilan, Mazandaran and Lorestan Provinces (Mansoorian 2000); Khuzestan Province (Mansoorian 2001, Massoud and Hedayeti-Far 1979, Elazian et al. 1979).

New records. Mazandaran Province: IR02-05 [2 ex.]; IR03-05 [3 ex.]; IR04-05 [3 ex.]; IR05-05 [3 ex.]; Markazi Province: IR51-05 [2 ex.], IR91-05 [6 ex.]; IR93-05 [1 ex.]; Khorasan Province: IR70-05 [1 ex.]; IR77-05 [1 ex.]; Gilan Province: IR8205 [1 ex.]; Lorestan Province; IR95-05 [39 ex.]; Fars Province: IR07-07 [22 ex.]; IR14-07[13 ex.]; IR26-07 [3 ex]; Seistan and Baluchestan Province: IR08-11 [12 ex.]; Hormozgan Province. IR17-11 [1 ex.].

Associated species. Melanoides tuberculatus, Thiara scabra, Grossuana sp., Galba truncatula, Acroloxus pseudolacustris, Planorbis intermixtus, Pseudobithynia zagrosia.

Distribution. Europe, Mediterranean, Iraq, Iran.

\section{Discussion}

The checklist of Iranian freshwater snails presented here shows a total of 73 species in 34 genera and 14 families. The records and taxonomic status of six species i.e. Neritina mesopotamica Martens, 1874, Bithynia cf. ejecta Mousson, 1874, B. rubens (Menke, 1830), Hydrobia acuta (Draparnaud, 1805), Hauffenia erythropomatia (Hauffen, 1856) and Stagnicola palustris (O.F. Müller, 1774) are questionable and needs new confirmation. Further, the genus Melanopsis needs revision as several species have been reported from Iran (i.e., Melanopsis variabilis, deserticola, buccinoidea and praemorsa), but without further study and additional materials it is not possible to establish under which name or names the Iranian populations should 
be placed. The genus Radix is richest in the number of the species. However, our list of Radix species from Iran contains the hitherto recorded nominal species, their taxonomic status remains to be explored. For the two species i.e. Stagnicola sp. and Anisus sp. further study and additional specimens are necessary to resolve the taxonomy of these taxa. The identification of the species of the genus Anisus is based on the anatomical features (Glöer and Meier-Brook 2008), so all former records of this genus are questionable and need new confirmation. Three species, Bithynia badiella (Küster, 1852), B. troschelii (Pasch, 1842) and Acroloxus lacustris (Linnaeus, 1758), are excluded from the list of Iranian freshwater snails, while Bithynia tentaculata most probably does not occur in Iran.

Of the 73 species reported in this paper, 12 species have a wide distribution (known from two or more bieogeographical regions), 9 species are Palaearctic, 4 species are W-Palaearctic and 8 species are "Middle East" (Iran, Iraq, Tadjikistan, Uzbekistan, Turkey, Syria, Israel) in their distribution. Insufficient knowledge hampers the determination of the biogeographic status of the rest of the species. Moreover, another $27(37 \%)$ of these species have been indicated as being endemic to Iran.

If we take generic diversity into consideration, we can see that only three genera i.e. Farsithyra Glöer \& Pešić 2009, Kaskakia gen. n. and Sarkhia gen. n. are endemic to Iran.

The species-richness of freshwater gastropods in our study was rather low one with an average of 2.12 species and a maximum of 6 spp. per sampling site. Only some common species occur in high abundances [ $>20$ ind./sampling site], abundances of most species being $<10$ ind./sampling site. Most sampling sites in our study were intermittent streams, with perennial surface water only present in the head water section near their source in the mountains. Further downstream, riverbeds are usually seasonally dry with occasionally some standing pools in their middle course (Pešić et al. 2012).

As expected, our current knowledge of the diversity of the freshwater snail fauna is far from being complete. For most Iranian provinces, all available data come from a few surveys with as objective the study of snails as vectors of digenetic trematodes of medical or veterinary importance (e.g., Mansoorian 1994, 1998, 2001). However, large portions of Iran remain unexplored and many important hydrological basins have never been sampled. The number of known species may hence only represent but a part of the total freshwater snail species number in Iran. For example, for Central Europe, an estimated total species number of about 150 appears appropriate (Glöer 2002).

However, the present study is exhaustive and constitutes the most complete list of freshwater snails in Iran, including a complete bibliography of research on the subject. Further studies should focus at a serious improvement of our knowledge on Iranian freshwater snails by intensive collecting activities in little known areas in order to close the large gaps in our knowledge on their diversity. Particularly some specific habitats such as springs and underground habitats are more or less unexplored but may prove to be a major source for freshwater biodiversity. 


\section{Acknowledgements}

We would like to thank Dr Martin Haase for identifying the hydrobioid snails Ecrobia grimmi and Helobia dalmatica. Further we are thankful to Anita Eschner for the loan of material from Edlauer's collection (Natural History Museum Vienna), to Edi Stöckli and Urs Wüest for the loan of material from Forcart's collection (Natural History Museum Basel), to Murtada Naser for Nerita spp. from Iraq, and to Dr David Walker who reviewed the English. This study was partly supported by the research project CBFEcoMTG from the Ministry of Science, Montenegro. Furthermore, we are grateful to Dr Eike Neubert (Switzerland), Dr Dirk van Damme (The Netherlands) and Dr Uli Bößneck (Germany) for their careful work and valuable comments.

\section{References}

Ancey CMF (1900) Description of New Species of Asiatic shells. The Nautilus 14 (7): 83-84. Annandale N (1921) The aquatic fauna of Seistan. Records of the Indian Museum 18: 235-253. Annandale N, Prashad B (1919) The Mollusca Fauna of the Inland Waters of Baluchistan and of Seistan. Records of the Indian Museum 18: 18-62.

Annandale N, Rao HS (1925) Materials for a revision of the recent Indian Lymnaeidae (Mollusca Pulmonata). Records of the Indian Museum 27: 137-189.

Bandel K (2001) The history of Theodoxus and Neritina connected with description and systematic evaluation of related Neritimorpha (Gastropoda). Mitteilungen aus dem GeologischPaläontologischen Institut der Universität Hamburg. 85: 65-164.

Bargues MD, Vigo M, Horak P, Dvorak J, Patzner RA, Pointier JP, Jackiewicz M, Meier-Brook C, Mas-Coma S (2001) European Lymnaeidae (Mollusca: Gastropoda), intermediate hosts of trematodiases, based on nuclear ribosomal DNA ITS-2 sequences. Infection, Genetics and Evolution 1 (2): 85-107. doi: 10.1016/S1567-1348(01)00019-3

Biggs HEJ (1936) Collecting Mollusca on the Iranian Plateau. The Nautilus 50: 8-13.

Biggs HEJ (1937) Mollusca of the Iranian Plateau. Journal of Conchology 20: 342-350.

Biggs HEJ (1971) Mollusca of the Iranian Plateau-III. Journal of Conchology 27: 211-220.

Bouchet Ph, Rocroi JP (2005) Classification and Nomenclator of Gastropod Families. Malacologia 47(1-2): 1-397.

Bourguignat JR (1864) Malacologie de l'Algérie. Histoire naturelle des animaux mollusques terrestres et fluviatiles. Vol. II. Paris (Chalamelle Ainé), 380 pp.

Brown DS (1994) Freshwater Snails of Africa and their Medical Importance. $2^{\text {nd }}$ ed. Taylor \& Francis, London, 608 pp.

Chu KY, Massoud J, Arfaa F (1968) Distribution and Ecology of Bulinus truncatus in Khuzestan, Iran. Bulletin of the World Health Organization 39: 607-637.

Dybowski W (1888) Die Gastropoden-Fauna des Kaspischen Meeres. Malakozoologische Blätter NF 10: 1-79. 
van Damme D (1984) The Freshwater Mollusca of Northern Africa. Dr. W. Junk Publishers, Dordrecht, $164 \mathrm{pp}$.

van Damme D, Ghamizi M, Soliman G, McIvor A, Seddon M (2010) The status and distribution of freshwater molluscs. In: Garcia N, Cuttelod A, Abdul Malak D (Eds) The status and distribution of freshwater biodiversity in Northern Africa. Gland, Switzerland, Cambridge, UK and Malaga, Spain, IUCN, Occasional Paper of the IUCN Species Survival Commission (ISBN: 978-2-8317-1271-0), Chapter 4: 30-49.

Eichwald E (1841) Fauna caspio-caucasia nonnullis observationibus novis. Petropoli. IV + 233 pp. + 2 pp. Corrigenda, 40 Taf.

Eliazian M, Tamiji Y, Akbarzadeh M, Hagh-Nazari J (1979) Snails from the northern parts of Iran (Caspian Sea). Archives of Razi Institute 31: 29-36.

Forcart L (1935) Die Mollusken der nordpersischen Provinz Masenderan und ihre tiergeographische Bedeutung. Archiv für Naturgeschichte, N.F. 4 (3): 404-447.

Ghasemi S, Zakaria M, Mola Hoveizeh N (2011) Abundance of Molluscs (Gastropods) at Mangrove Forests of Iran. Journal of American Science 7 (1): 660-669.

Glaubrecht M (1993) Mapping the diversity: Geographical distribution of the freshwater snail Melanopsis (Gastropoda: Cerithioidea: Melanopsidae) with focus on its systematics in Mediterranean basin. Miutteilungen aus dem Hamburgischen Museum und Institut 90: 41-97.

Glöer P (2002) Die Süßwassergastropoden Nord- und Mitteleuropas. Bestimmungsschlüssel, Lebensweise, Verbreitung. Die Tierwelt Deutschlands, 73, 327 pp.

Glöer P, Bössneck U (2007) Zur Identität von Gyraulus piscinarum Bourguignat 1852 mit der Beschreibung von G. bekaensis n. sp. (Gastropoda: Planorbidae). Mollusca 25 (2): 139-146 Glöer P, Meier-Brook C (2008) Redescription of Anisus septemgyratus (Rossmässler, 1835) and Anisus leucostoma (Millet, 1813) (Gastropoda: Planorbidae). Mollusca 26: 89-94.

Glöer P, Pešić V (2006) On the identity of Bithynia graeca gen. n. (Westerlund, 1879) with the description of three new Pseudobithynia irana n. gen species from Iran and Greece (Gastropoda: Bithyniidae). Malakologische Abhandlungen 24: 29-36.

Glöer P, Pešić V (2009) New freshwater gastropod species of the Iran (Gastropoda: Stenothyridae, Bithyniidae, Hydrobiidae). Mollusca 27 (1): 33-39.

Glöer P, Pešić V (2010) The Planorbis species of the Balkans with the description of Planorbis vitojensis sp. n. (Gastropoda: Planorbidae). Journal of Conchology 40: 249-257.

Götting K-J (2008) Meeres-Gehäuseschnecken Deutschlands, Bestimmungsschlüssel, Lebensweise, Verbreitung. Die Tierwelt Deutschlands 80: 1-179.

Haase M, Naser MD, Wilke T (2010) Ecrobia grimmi in brackish Lake Sawa, Iraq: indirect evidence for long-distance dispersal of hydrobiid gastropods (Caenogastropoda: Rissooidea) by birds. Journal of Molluscan studies 76: 101-105. doi: 10.1093/mollus/eyp051

Heller J, Mordan P, Ben-Ami F, Sivan N (2005) Conchometrics, systematics and distribution of Melanopsis (Mollusca: Gastropoda) in the Levant. Zoological Journal of the Linnean Society 144 (2): 229-260. doi: 10.1111/j.1096-3642.2005.00172.x

Hubendick B (1951) Recent Lymnaeidae. Their variation, morphology, taxonomy, nomenclature and distribution. Kungliga Svenska Vetenskapsakademiens Handlingar. Fjärde Serien 3 (1): 1-223. 
Issel A (1865) Catalogo dei Molluschi raccolti dalla Missione Italiana in Persia, aggiuntavi la descrizione delle specie nuove o poco note. Memorie della Reale Accademia delle Scienze di Torino, (Ser. II) 23 [1866]: 387-439, 3 tavv. Torino. [Separatum: pp. 1-55, 3 tavv. Stamperia Reale, Torino 1865.]

Kantor YI, Vinarski MV, Schileyko AA, Sysoev AV (2009) Catalogue of the Continental Mollusks of Russia and adjacent territories. Version 2.3 (published online on December 22, 2009: http://www.ruthenica.com/documents/Continental_Russian_molluscs_ver2-3.pdf)

Mandahl-Barth G (1968) Revision of the African Bithyniidae (Gastropoda Prosobranchia). Revue de zoologie et de botanique africaines 78 (1-2): 129-159.

Martens E von (1874) Ueber vorderasiatische Conchylien nach den Sammlungen des Prof. Hausknecht. Novitates conchologicae. Supplement V.: 63-82 (Gastropoda).

Martens E von (1879) Die Gattung Neritina. Systematisches Conchylien Cabinet, II. 10, 303 pp.

Mansoorian A (1986) A practical guide to the identification of the freshwater snails of Iran. Iranian Journal Public Health 15 (1-2): 41-53. [In persian]

Mansoorian A (1998) Some freshwater snails from Iran. In: R Bieler R, Mikkelsen PM (Eds) Abstracts of World Congress of Malacology, July 1998, Washington DC, 206.

Mansoorian A (1994) Freshwater snails of Iran. Scientific publication of School of Public Health \& Institute of Public Health Research, Technical series 2145: 1374.

Mansoorian A (2000) Some freshwater snails from Northern Iran. Iranian Journal Public Health 29 (1-4): 77-82.

Mansoorian A (2001) Freshwater Gastropod of Khuzestan Province, South-West Iran. Iranian International Journal of Science 2 (2): 1-9.

Massoud J, Hedayeti-Far M (1979) Freshwater mollusk fauna of the Khuzestan and KhorramBad areas in Southwestern Iran. Malacological Review 12: 96.

Meier-Brook C (1983) Taxonomic studies on Gyraulus (Gastropoda: Planorbidae). Malacologia $24(1-2)$ : 1-113.

Mousson MA (1874) Coquilles terrestres et fluviatiles recueillies par M. le Dr Alexandre Schlaefli en Orient. Journal de Conchyliologie (5th series), 22: 1-60.

Nesemann H, Sharma S, Sharma G, Khanal SN, Pradhan B, Shah DN, Tachamo RD (2007) Aquatic invertebrates of the Ganga River System. Mollusca, Annelida, Crustacea (in part), $1,263 \mathrm{pp}$.

Neubert E (1998) Annotated checklist of the terrestrial and freshwater molluscs of the Arabian Peninsula with description of new species. Fauna of Arabia 17: 333-461.

Pešić V, Saboori A (2007) A checklist of the water mites (Acari: Hydrachnidia) of Iran. Zootaxa 1473: 45-68.

Pešić V, Smit H, Saboori A (2012) Water mites delineating the Oriental and Palaearctic regions - the unique fauna of southern Iran, with description of one new genus, one new subgenus and 14 new species. Zootaxa 3330: 1-67.

Pfenninger M, Cordellier M, Streit B (2006) Comparing the efficacy of morphologic and DNA-based taxonomy in the freshwater gastropod genus Radix (Basommatophora, Pulmonata). BiomedCentral Evolutionary Biology 14 pp. BMC Evolutionary Biology 2006, 6:100 doi: 10.1186/1471-2148-6-100 
Prashad B (1921) Report on the freshwater gastropod molluscs of lower Mesopotamia. Part III. The families Neritidae, Hydrobiidae and Melaniidae, Records of Indian Museum, 18: 215-26.

Radoman P (1983) Hydrobioidea a superfamily of Prosobranchia (Gastropoda). I. Systematics. Monographs 547, Serbian Academy of Sciences and Arts, 256 pp.

Ramakrishna, Dey A (2007) Handbook on Indian Freshwater Molluscs. Zoological Survey of India, $399 \mathrm{pp}$.

Schniebs K, Glöer P, Vinarski MV, Hundsdoerfer AK (2011) Intraspecific morphological and genetic variability in Radix balthica (Linnaeus 1758) (Gastropoda: Basommatophora: Lymnaeidae) with morphological comparison to other European Radix species. Journal of Conchology 40 (6): 657-678.

Schütt H (1973) Einige Süsswassermollusken der zentralen Hochtäler Westasiens. Basteria 37: $31-38$.

Starmühlner F (1961) Eine kleine Molluskenausbeute aus Nord- und Ostiran. Sitzungsberichte der österreichischen Akademie der Wissenschaften, mathematisch-naturwissenschaftliche Klasse, Abteilung I, 170 (3-4): 89-99.

Starmühlner F (1965) Eine weiterer Beitrag zur Wassermolluskenfauna des Iran. Sitzungsberichte der österreichischen Akademie der Wissenschaften, mathematisch-naturwissenschaftliche Klasse, Abteilung I, 174 (5-6): 171-183.

Starmühlner F, Edlauer A (1957) Ergebnisse der Österreichischen Iran-Expedition 1949/50 (Mit Berücksichtigung der Ausbeute der Österreichischen Iran-Expedition 1956): Beiträge zur Kenntnis der Molluskenfauna des Iran. Sitzungsberichte der österreichischen Akademie der Wissenschaften, mathematisch-naturwissenschaftliche Klasse, Abteilung I, 166 (9/10): 435-494.

Subba Rao NV (1989) Handbook Freshwater Molluscs of India. Zoological Survey of India, Calcutta, 289 pp.

Yılıdırım MZ (1994) Türkiye Prosobranchia (Gastropoda: Mollusca) Türleri ve Zoocoğrafik Yayıhşları. Turkish Journal of Zoology 23: 877-900.

Westerlund CA (1886) Fauna der in der paläarctischen Region lebenden Binnenconchylien. 6: Fam. Ampullaridae, Paludinidae, Rissoidae, Assiminidae, Valvatidae, Melanidae \& Neritidae. Lund (Ohlsson), 156+13 pp.

Zhadin VI (1952) Mollusks of Fresh and Brackish Waters of the U.S.S.R. Academie of Sciences of the Union of Soviet Socialist Republics (translated by the Israel Program of Scientific Translations, Jerusalem 1965), xvi + 368 pp. 


\section{Appendix}

List of sampling sites.

\begin{tabular}{|c|c|c|c|c|c|}
\hline & code & sampling site & $\begin{array}{c}\text { GPS-coordinates } \\
{[\mathrm{m} \text { asl. }]}\end{array}$ & habitat & date \\
\hline 1 & IR01-05 & $\begin{array}{l}\text { Mazandaran province, Nowshahr } \\
\text { city (near Caspian Sea) }\end{array}$ & $\begin{array}{c}51^{\circ} 31^{\prime} \mathrm{E}, 36^{\circ} 38^{\prime} \mathrm{N} \\
{[-28]}\end{array}$ & pond & 18.06.2005 \\
\hline 2 & IR02-05 & $\begin{array}{c}\text { Mazandaran province, road to } \\
\text { Kandelous }\end{array}$ & no coordinates & spring & 18.06 .2005 \\
\hline 3 & IR03-05 & Markazi province, road to Khomeyn & no coordinates & stream & 27.06 .2005 \\
\hline 4 & IR05-05 & $\begin{array}{c}\begin{array}{c}\text { Lorestan province, Khorramabad } \\
\text { area. }\end{array} \\
\end{array}$ & no coordinates & stream & 24.06 .2005 \\
\hline 5 & IR04-05 & $\begin{array}{c}\text { Khorasan province, } 25 \mathrm{~km} \text { to } \\
\text { Bojnurd River }\end{array}$ & no coordinates & stream & 07.07.2005 \\
\hline 6 & IR51-05 & $\begin{array}{c}\text { Markazi Province, Bolagh stream } 10 \\
\text { km after Shahzand city (in Shahzand } \\
\text { to Pole Doab Road) }\end{array}$ & no coordinates & stream & 04.06 .2005 \\
\hline 7 & IR61-05 & Khorrasan Province, Akhlamad & $\begin{array}{c}58^{\circ} 57^{\prime} \mathrm{E}, 36^{\circ} 40^{\prime} \mathrm{N} \\
{[\text { ca. 2000] }}\end{array}$ & waterfall & 04.06 .2005 \\
\hline 8 & IR62-05 & $\begin{array}{c}\text { Khorrasan Province, Golmakan, } \\
\text { Cheshmeh Sebz }\end{array}$ & $\begin{array}{c}59^{\circ} 15^{\prime} \mathrm{E}, 36^{\circ} 15^{\prime} \mathrm{N} \\
{[\text { ca. 2000] }}\end{array}$ & spring & 04.06 .2005 \\
\hline 9 & IR63-05 & $\begin{array}{c}\text { Khorrasan Province, Gojki road to } \\
\text { Kalat (ca. } 94 \mathrm{~km} \text { to Kalat) }\end{array}$ & $\begin{array}{c}59^{\circ} 45^{\prime} \mathrm{E}, 36^{\circ} 35^{\prime} \mathrm{N} \\
\text { [ca. } 1400 \text { ] }\end{array}$ & $\begin{array}{c}\text { rheohelocrenic } \\
\text { spring }\end{array}$ & 05.06 .2005 \\
\hline 10 & IR64-05 & $\begin{array}{c}\text { Khorrasan Province, Gojki road to } \\
\text { Kalat (ca. } 94 \mathrm{~km} \text { to Kalat) }\end{array}$ & $\begin{array}{c}59^{\circ} 45^{\prime} \mathrm{E}, 36^{\circ} 35^{\prime} \mathrm{N} \\
{[\text { ca. } 1400]}\end{array}$ & stream & 05.06 .2005 \\
\hline 11 & IR66a-05 & $\begin{array}{c}\text { Khorrasan Province, spring at } \\
\text { Masshad-Kalat road ( } 35 \mathrm{~km} \text { to Kalat) }\end{array}$ & no coordinates & spring & 05.06 .2005 \\
\hline 12 & IR67-05 & $\begin{array}{c}\text { Khorrasan Province, river near Kalat } \\
\text { city }\end{array}$ & $\begin{array}{c}59^{\circ} 45^{\prime} \mathrm{E}, 36^{\circ} 58^{\prime} \mathrm{N} \\
{[\text { ca. } 1900]}\end{array}$ & river & 05.06 .2005 \\
\hline 13 & IR68-05 & $\begin{array}{c}\text { Khorrasan Province, Mach stream (in } \\
\text { Moghan road), } 16 \mathrm{~km} \text { to Moghan }\end{array}$ & $\begin{array}{c}59^{\circ} 31^{\prime} \mathrm{E}, 35^{\circ} 10^{\prime} \mathrm{N} \\
{[\text { ca. 2000] }}\end{array}$ & stream & 06.06 .2005 \\
\hline 14 & IR70-05 & \begin{tabular}{|c|}
$\begin{array}{c}\text { Khorrasan Province, Kaskak stream } \\
\text { in Kaskak village }\end{array}$ \\
\end{tabular} & $\begin{array}{c}59^{\circ} 10^{\prime} \mathrm{E}, 35^{\circ} 25^{\prime} \mathrm{N} \\
{[\text { ca. } 1800]}\end{array}$ & stream & 07.06 .2005 \\
\hline 15 & IR76-05 & $\begin{array}{c}\text { Khorrasan Province, Kharv stream in } \\
\text { Kharv city ( } 25 \mathrm{~km} \text { to Neishabour })\end{array}$ & $\begin{array}{c}59^{\circ} 5^{\prime} \mathrm{E}, 36^{\circ} 12^{\prime} \mathrm{N} \\
{[\text { ca. 2200] }}\end{array}$ & stream & 10.06 .2005 \\
\hline 16 & IR77-05 & $\begin{array}{c}\text { Khorrasan Province, Koh Sorkh } \\
\text { stream (in Koh Sorkh city, ca. } 35 \mathrm{~km} \\
\text { to Kashmar city) }\end{array}$ & $\begin{array}{c}59^{\circ} 25^{\prime} \mathrm{E}, 36^{\circ} 25^{\prime} \mathrm{N} \\
{[\text { ca. 2200] }}\end{array}$ & stream & 10.06 .2005 \\
\hline 17 & IR78-05 & $\begin{array}{c}\text { Khorrasan Province, Zou Eram } \\
\text { spring in Zou Eram village (near } \\
\text { Shirvan city) }\end{array}$ & $\begin{array}{c}57^{\circ} 40^{\prime} \mathrm{E}, 37^{\circ} 20^{\prime} \mathrm{N} \\
\text { [ca. 1600] }\end{array}$ & spring & 11.06 .2005 \\
\hline 18 & IR78a-05 & $\begin{array}{c}\text { Khorrasan Province, spring } 1 \text { near } \\
\text { Zou Eram spring in Zou Eram } \\
\text { village (near Shirvan city) }\end{array}$ & $\begin{array}{l}\text { no coordinates } \\
\text { [ca. 1600] }\end{array}$ & spring & 11.06 .2005 \\
\hline 19 & IR78b-05 & $\begin{array}{c}\text { Khorrasan Province, spring } 2 \text { near } \\
\text { to Zou Eram spring in Zou Eram } \\
\text { village (near Shirvan city) }\end{array}$ & $\begin{array}{c}\text { no ccordiantes } \\
\text { [ca. 1600] }\end{array}$ & spring & 11.06 .2005 \\
\hline
\end{tabular}




\begin{tabular}{|c|c|c|c|c|c|}
\hline & code & sampling site & $\begin{array}{c}\text { GPS-coordinates } \\
{[\mathrm{m} \text { asl.] }}\end{array}$ & habitat & date \\
\hline 20 & IR79-05 & $\begin{array}{c}\text { Khorrasan Province, Baba Aman Park } \\
\text { spring (ca. } 5 \mathrm{~km} \text { to Bojnurd city) }\end{array}$ & $\begin{array}{c}57^{\circ} 24^{\prime} \mathrm{E}, 37^{\circ} 25^{\prime} \mathrm{N} \\
{[\text { ca. } 1300]}\end{array}$ & spring & 11.06.2005 \\
\hline 21 & IR82-05 & $\begin{array}{c}\text { Gilan Province, Bandar Anzali } \\
\text { Lagoon }\end{array}$ & $49^{\circ} 27^{\prime} \mathrm{E}, 37^{\circ} 26^{\prime} \mathrm{N}$ & wetland & 16.06.2005 \\
\hline 22 & IR87-05 & $\begin{array}{l}\text { Markazi Province, Ashtian to Arak } \\
\text { road (ca. } 5 \mathrm{~km} \text { after Ashtian) }\end{array}$ & $\begin{array}{c}50^{\circ} 01^{\prime} \mathrm{E}, 34^{\circ} 34^{\prime} \mathrm{N} \\
{[\text { ca. 1800] }}\end{array}$ & pool & 21.06.2005 \\
\hline 23 & IR88-05 & $\begin{array}{c}\text { Markazi Province Aman Abad spring } \\
\text { in Anjedan road before Aman Abad } \\
\text { village (ca. } 5 \mathrm{~km} \text { to Aman Abad } \\
\text { village) }\end{array}$ & $\begin{array}{c}49^{\circ} 48^{\prime} \mathrm{E}, 33^{\circ} 55^{\prime} \mathrm{N} \\
{[\text { ca. } 1700]}\end{array}$ & spring & 22.06 .2005 \\
\hline 24 & IR89-05 & $\begin{array}{l}\text { Markazi Province, Cheshmeh Shater } \\
\text { in Arak to Khomein road (8 km after } \\
\text { Arak) }\end{array}$ & $\begin{array}{c}49^{\circ} 45^{\prime} \mathrm{E}, 34^{\circ} 08^{\prime} \mathrm{N} \\
{[\text { ca. } 1700]}\end{array}$ & pool & 22.06 .2005 \\
\hline 25 & IR90-05 & $\begin{array}{c}\text { Markazi Province, stream } 2 \mathrm{~km} \text { after } \\
\text { Hassan Abad (in Arak to Khomein } \\
\text { road) }\end{array}$ & $\begin{array}{c}49^{\circ} 52^{\prime} \mathrm{E}, 33^{\circ} 50^{\prime} \mathrm{N} \\
{[\text { ca. } 1700]}\end{array}$ & stream & 22.06.2005 \\
\hline 26 & IR91-05 & $\begin{array}{l}\text { Markazi Province, Varcheh spring } \\
\text { in Emamzadeh Varcheh village (in } \\
\text { Arak to Khomein road, ca. } 20 \mathrm{~km} \text { to } \\
\text { Khomein) }\end{array}$ & $\begin{array}{c}49^{\circ} 55^{\prime} \mathrm{E}, 33^{\circ} 49^{\prime} \mathrm{N} \\
{[\text { ca. } 1700]}\end{array}$ & spring & 22.06.2005 \\
\hline 27 & IR93-05 & $\begin{array}{c}\text { Markazi Province, stream near } \\
\text { Astaneh city (Azna Aligudarz cross } \\
\text { way) }\end{array}$ & $\begin{array}{c}49^{\circ} 24^{\prime} \mathrm{E}, 33^{\circ} 55^{\prime} \mathrm{N} \\
{[\text { ca. } 2400]}\end{array}$ & stream & 23.06.2005 \\
\hline 28 & IR94-05 & $\begin{array}{l}\text { Lorestan Province, Darband stream } \\
\text { in Darband village (Azna to Dorood } \\
\text { road, ca. } 16 \mathrm{~km} \text { to Azna) }\end{array}$ & $\begin{array}{c}49^{\circ} 17^{\prime} \mathrm{E}, 33^{\circ} 25^{\prime} \mathrm{N} \\
\text { [ca. } 1800]\end{array}$ & stream & 23.06.2005 \\
\hline 29 & IR95-05 & $\begin{array}{c}\text { Lorestan Province, Dareh Takht } \\
\text { stream in Dareh Takht village (13 } \\
\text { km to Azna city) }\end{array}$ & $\begin{array}{c}33^{\circ} 22^{\prime} \mathrm{N}, 49^{\circ} 22^{\prime} \mathrm{E} \\
\text { [ca. 2800] }\end{array}$ & stream & 23.06.2005 \\
\hline 30 & IR105-05 & $\begin{array}{c}\text { Kermanshah Province, Firoozan } \\
\text { stream in Firoozan village }\end{array}$ & $34^{\circ} 25^{\prime} \mathrm{N}, 48^{\circ} 11^{\prime} \mathrm{E}$ & stream & 27.06 .2005 \\
\hline 31 & IR106-05 & $\begin{array}{c}\text { Kermanshah Province, Sar Pol } \\
\text { Kangarar stream in Sar Pol Kangarar } \\
\text { village }\end{array}$ & $34^{\circ} 30^{\prime} \mathrm{N}, 47^{\circ} 55^{\prime} \mathrm{E}$ & stream & 27.06 .2005 \\
\hline 32 & IR107-05 & $\begin{array}{l}\text { Kermanshah Province, spring near } \\
\text { Sarabe - Sarkh city }\end{array}$ & no coordinates & spring & 27.06 .2005 \\
\hline 33 & IR108-05 & $\begin{array}{l}\text { Kermanshah Province, stream } \\
\text { Gamasiab in village Gamasiab }\end{array}$ & $34^{\circ} 27^{\prime} \mathrm{N} 47^{\circ} 45^{\prime} \mathrm{E}$ & stream & 27.06 .2005 \\
\hline 34 & IR07-07 & $\begin{array}{l}\text { Fars Province, Dasht Arzhan village } \\
\text { (in Shiraz to Kazerum road) }\end{array}$ & $\begin{array}{c}29^{\circ} 39^{\prime} \mathrm{N}, 51^{\circ} 59^{\prime} \mathrm{E} \\
{[\text { ca. } 2300]}\end{array}$ & stream & 04.08 .2007 \\
\hline 35 & IR13-07 & $\begin{array}{l}\text { Fars Province, AtashKadeh spring, } \\
\text { Ardeshir palace in Firooz Abad }\end{array}$ & $\begin{array}{c}28^{\circ} 54^{\prime} \mathrm{N}, 52^{\circ} 32^{\prime} \mathrm{E} \\
{[1683]}\end{array}$ & $\begin{array}{c}\text { limnocrenic } \\
\text { spring }\end{array}$ & 05.08.2007 \\
\hline 36 & IR14-07 & $\begin{array}{c}\text { Fars Province, Firooz Abad city, Kay } \\
\text { Zarrin village }\end{array}$ & $\begin{array}{c}28^{\circ} 53^{\prime} \mathrm{N}, 52^{\circ} 32^{\prime} \mathrm{E} \\
{[1711]}\end{array}$ & stream & 05.08.2007 \\
\hline 37 & IR17-07 & $\begin{array}{c}\text { Fars Province, Shiraz to Firooz Abad } \\
\text { road, Ebrahim Abad village, Ebrahim } \\
\text { Abad stream }\end{array}$ & $29^{\circ} 00^{\prime} \mathrm{N}, 52^{\circ} 34^{\prime} \mathrm{E}$ & stream & 06.08.2007 \\
\hline
\end{tabular}




\begin{tabular}{|c|c|c|c|c|c|}
\hline & code & sampling site & $\begin{array}{c}\text { GPS-coordinates } \\
{[\mathrm{m} \text { asl. }]}\end{array}$ & habitat & date \\
\hline 38 & IR21-07 & Lorestan Province, Mode Abad village & $\begin{array}{c}33^{\circ} 35^{\prime \prime} \mathrm{N}, 48^{\circ} 37^{\prime} \mathrm{E} \\
{[1723]}\end{array}$ & stream & 10.08.2007 \\
\hline 39 & IR26-07 & $\begin{array}{l}\text { Lorestan Province, road from } \\
\text { Boroujerd to Khorram Abad city }\end{array}$ & $\begin{array}{c}33^{\circ} 30^{\prime} \mathrm{N}, 48^{\circ} 44^{\prime} \mathrm{E} \\
{[1660]}\end{array}$ & $\begin{array}{c}\text { limnocrenic } \\
\text { spring }\end{array}$ & 10.08.2007 \\
\hline 40 & IR27-07 & $\begin{array}{l}\text { Markazi Province, Aman Abad (near } \\
\text { Arak city) }\end{array}$ & $\begin{array}{c}33^{\circ} 59^{\prime} \mathrm{N}, 49^{\circ} 52^{\prime} \mathrm{E} \\
{[1775]}\end{array}$ & pool & 11.08.2007 \\
\hline 41 & IR08-11 & $\begin{array}{c}\text { Seistan Province, Chabahar, Sharak } \\
\text { village, Qanat } 1\end{array}$ & $\begin{array}{c}26^{\circ} 02^{\prime} \mathrm{N}, 61^{\circ} 04^{\prime} \mathrm{E} \\
{[264]}\end{array}$ & qanat (spring) & 13.07.2011 \\
\hline 42 & IR08a-11 & $\begin{array}{l}\text { Seistan va Baluchestan Province, } \\
\text { Chabahar, Sharak village, Qanat } 2 \\
\text { (ca. } 100 \mathrm{~m} \text { from Qanat } 1 \text { ) }\end{array}$ & no coordinates & qanat (spring) & 13.07.2011 \\
\hline 43 & IR09-11 & $\begin{array}{l}\text { Seistan va Baluchestan Province, } \\
\text { Chabahar, Shirgovaz - Machkor } \\
\text { stream, } 45 \mathrm{~m} \text { asl. }\end{array}$ & $25^{\circ} 47^{\prime} \mathrm{N}, 61^{\circ} 28^{\prime} \mathrm{E}$ & stream & 14.07.2011 \\
\hline 44 & IR10-11 & $\begin{array}{c}\text { Seistan va Baluchestan Province, } \\
\text { Chabahar, Hootgat Bala river }\end{array}$ & $\begin{array}{c}25^{\circ} 48^{\prime} \mathrm{N}, 61^{\circ} 31^{\prime} \mathrm{E} \\
{[57]}\end{array}$ & river & 14.07.2011 \\
\hline 45 & IR14-11 & $\begin{array}{c}\text { Hormozgan Province, Bandar Abass, } \\
\text { Khorgoo village before hot water } \\
\text { spring }\end{array}$ & $\begin{array}{c}27^{\circ} 29^{\prime} \mathrm{N}, 56^{\circ} 28^{\prime} \mathrm{E} \\
{[125]}\end{array}$ & saline stream & 14.07.2011 \\
\hline 46 & IR15-11 & $\begin{array}{c}\text { Hormozgan Province, Bandar Abass, } \\
\text { Khorgoo village before hot water } \\
\text { spring, small pool near 14-11 }\end{array}$ & $\begin{array}{c}27^{\circ} 29^{\prime} \mathrm{N}, 56^{\circ} 28^{\prime} \mathrm{E} \\
{[113]}\end{array}$ & $\begin{array}{l}\text { pool (saline } \\
\text { water) }\end{array}$ & 16.07.2011 \\
\hline 47 & IR17-11 & $\begin{array}{c}\text { Hormozgan Province, Bandar Abass, } \\
\text { Siahoo Qanat in Siahoo village }\end{array}$ & $\begin{array}{c}27^{\circ} 46^{\prime} \mathrm{N}, 56^{\circ} 20^{\prime} \mathrm{E} \\
{[630]}\end{array}$ & qanat (spring) & 18.07.2011 \\
\hline 48 & IR18-11 & $\begin{array}{c}\text { Hormozgan Province, Bandar Abass, } \\
\text { Taleguerdoo village, Poshtekeno } \\
\text { spring, upper part of stream }\end{array}$ & $\begin{array}{c}27^{\circ} 49^{\prime} \mathrm{N}, 56^{\circ} 24^{\prime} \mathrm{E} \\
{[836]}\end{array}$ & stream & 18.07.2011 \\
\hline 49 & IR19-11 & $\begin{array}{c}\begin{array}{c}\text { Hormozgan Province, Bandar Abass, } \\
\text { Banglayan village }\end{array} \\
\end{array}$ & $\begin{array}{c}27^{\circ} 46^{\prime} \mathrm{N}, 56^{\circ} 32^{\prime} \mathrm{E} \\
{[577]}\end{array}$ & stream & 18.07.2011 \\
\hline 50 & IR20-11 & $\begin{array}{l}\text { Hormozgan Province, Bandar Abass, } \\
\text { Bandar Kamir to Bandar Lenhueh } \\
\text { road, ca } 80 \mathrm{~km} \text { to Bandar Abass, } \\
\text { saline stream near Dezhgan }\end{array}$ & $\begin{array}{c}26^{\circ} 53^{\prime} \mathrm{N}, 55^{\circ} 16^{\prime} \mathrm{E} \\
{[20]}\end{array}$ & saline stream & 20.07.2011 \\
\hline 51 & IR48-05 & $\begin{array}{c}\text { Tehran Province, Elbrus Mt., } \\
\text { Shahrestanak River }\end{array}$ & & river & 18.08 .2003 \\
\hline
\end{tabular}


